Review

\title{
B-glucans from Grifola frondosa and Ganoderma lucidum in breast cancer: an example of complementary and integrative medicine
}

\author{
Paola Rossi ${ }^{1}$, Raffaele Difrancia², Vincenzo Quagliariello ${ }^{3}$, Elena Savino ${ }^{4}$, Paolo \\ Tralongo $^{5}$, Cinzia Lucia Randazzo ${ }^{6}$ and Massimiliano Berretta7 \\ ${ }^{1}$ Department of Biology and Biotechnology "L. Spallanzani", University of Pavia, Italy \\ ${ }^{2}$ Gruppo Oncologico Ricercatori Italiani, GORI onlus, Pordenone, Italy \\ ${ }^{3}$ Department of Abdominal Oncology, National Cancer Institute, IRCCS - Foundation G. Pascale, Naples, Italy \\ ${ }^{4}$ Department of Earth and Environmental Science, University of Pavia, Italy \\ ${ }^{5}$ Oncology Division Umberto I Hospital, Siracusa, Italy \\ ${ }^{6}$ Department of Agricultural, Food and Environment, University of Catania, Italy \\ ${ }^{7}$ Department of Medical Oncology, National Cancer Institute, IRCCS, Aviano (PN), Italy \\ Correspondence to: Massimiliano Berretta, email: mberretta@cro.it \\ Keywords: G. lucidum; G. frondosa; breast cancer; immunomodulation; microbiota \\ Received: February 03, $2018 \quad$ Accepted: March 07, $2018 \quad$ Published: May 15, 2018 \\ Copyright: Rossi et al. This is an open-access article distributed under the terms of the Creative Commons Attribution License 3.0 \\ (CC BY 3.0), which permits unrestricted use, distribution, and reproduction in any medium, provided the original author and source \\ are credited.
}

\section{ABSTRACT}

Culinary and medicinal mushrooms are widely used in Asian countries, both as dietary supplements and as nutraceutical foods. They have recently become popular in Europe, as well, for their nutritional and health benefits. In particular, epidemiological studies conducted in Asia suggest that mushroom intake, together with other phytotherapy substances, protects against cancer, specifically gastrointestinal (GI) and breast cancers. Most of the data come from in vitro studies and in vivo experimental animal models. Therefore, in order to translate the updated knowledge to clinical research (i.e., from bench to bedside) a systematic translational research program should be initiated. Future randomized controlled trials comparing the effects of G. frondosa and G. Iucidum on conventional treatment outcomes are warranted.

The purpose of this review was to describe the emerging mechanisms of action of the mushrooms' anticancer functions which makes their use in clinical practice so promising. Clinical effects of mycotherapy (specifically, the use of Ganoderma lucidum and Grifola frondosa) on long-term survival, tumor response, host immune functions, inflammation, and QoL in cancer patients were also addressed. Adverse events associated with mycotherapy were also investigated. Emerging data point to a potential role of $\mathbf{G}$. lucidum for modulating the carcinogenic potential of GI microbiota, which suggests a new complementary and integrated approach to breast cancer treatment.

\section{INTRODUCTION}

Complementary and integrative medicine (CIM) is a relatively new approach becoming an increasingly popular and visible component of oncology care. CIM combines complementary practices and conventional medicine in a coordinated way [1]. Complementary and alternative medicine, which is commonly known by the acronym "CAM," falls within the spectrum of CIM. CAM includes a wide range of products (herbs, vitamins, minerals, and probiotics) and medical practices that denotes both the combined use of complementary or non- 
mainstream practices with conventional medicine and the use of certain practices instead of conventional medicine [2]: practices and substances are defined as "alternative" when they are used in place of conventional medicine and "complementary" when they are used together with conventional medicine $[1,3]$.

Recently, the use of mycotherapy, a type of CAM, has been associated with positive impacts in cancer patients in terms of responses to treatment, reductions in side effects, and improvements in quality of life (QoL).

It is estimated that $38 \%$ of the general public in the United States (U.S.) uses CAM [4], and 69\% of the population of Australia has used at least 1 form of CAM in the past 12 months [5]. A recent Italian survey reported that $49 \%$ of cancer patients used CAM during the course of their diseases [3]. One of the most promising types of $\mathrm{CAM}$ in cancer patients is mycotherapy, which is derived from traditional Chinese medicine (TCM).

In the year 2000, there were approximately 56 million deaths worldwide from all causes. Cancers were responsible for $12 \%$ of these deaths. Roughly 5.3 million men and 4.7 million women developed cancer and 6.2 million people died from the disease. According to the World Cancer Report by the World Health Organization, cancer rates could increase by $50 \%$ to 15 million new cases by 2020 [6]. Breast cancer (BC) is one of the most common primary malignancies worldwide, with an estimated 249,260 new cases in the U.S. during 2016 and 40,890 attributable deaths the same year. It is the second leading cause of cancer-related mortality in the U.S. and it has been estimated that 1 in 8 women will develop $\mathrm{BC}$ at some point during their lifetimes [7].

Conventional medicine approaches, including chemotherapy (CT), hormone-targeted therapies, immunotherapies, and radiotherapy (RT), are routinely used to treat BC patients: their uses depend on clinicopathological factors, disease stage, and biological characteristics of the tumors. A variety of adverse events are associated with these treatments, such as myelosuppression, gastrointestinal (GI) discomfort and disorders, alopecia, fatigue, infection, cardiotoxicity, respiratory toxicity, and neurotoxicity. These side effects influence patients' long-term compliance to medications and lower quality of life (QoL) [8]. Due in part to these effects, as well as other reasons, cancer patients are likely to request CAM - in both early and late stages of the disease course: the unfavorable outcomes in a substantial percentage of cases leads patients to 'leave no stone unturned' and seek out every option for care, and the heavy toxicities often associated with traditional therapies lead patients to investigate alternatives to the prescribed therapies or, more simply, to seek out substances presumed to reduce the side effects of conventional therapies [3].

One of the most promising integrative approaches in cancer therapy is mycotherapy. This approach appears to have several benefits: (i) improvement in the overall response rate during oncological treatment, (ii) enhanced immunity due to the stimulation of T-lymphocyte proliferation, and (iii) reduction of some adverse events (e.g., nausea and insomnia) due to CT [9]. Medicinal mushrooms have been used for hundreds of years, mainly in Asian countries, for the treatment of infections. More recently, they have also been used in the treatment of pulmonary disease and cancer. They have been approved as adjuncts to standard cancer treatments in Japan and China for more than 30 years and have an extensive clinical history of safe use as single agents or combined with CT.

The anticancer activities of mushrooms have been linked primarily to the modulation of the immune system by branched polysaccharides (glucans), sesquiterpenes, glycoproteins, or peptide/protein-bound polysaccharides [10]. Moreover, mushrooms contain minerals, vitamins (e.g., thiamin, riboflavin, ascorbic acid, and vitamin D), amino acids, and other organic compounds that contribute to the overall health benefits [10]. Some of these natural mushroom compounds have demonstrated specific activity against aberrantly activated signaling pathways in cancer cells and have modulated specific molecular targets of cell functions, including cell proliferation, cell survival, and angiogenesis [10]. These key characteristics of mycotherapy are primarily associated with 2 mushrooms: Ganoderma lucidum and Grifola frondosa [9, 11-13]. Unfortunately, the small number of studies with high methodological quality limit the application of mycotherapy data.

The purpose of this review was to critically evaluate the described effects of the edible G. frondosa (Maitake) and G. lucidum (Reishi) mushrooms in patients with BC. Ideally, this review will inspire new scientists to pave the way for new mycotherapy studies in humans, which will begin to bridge the gap between the long history of Eastern medicine and the newer, conventional Western medicine [4-6]. Two authors independently performed a systematic literature search using several electronic databases: PubMed, EMBASE, AMED, Scopus, the Cochrane Library, the National Institutes of Health, and the National Center for Complementary and Alternative Medicine (//:nccam.nih.gov/clinicaltrials/alltrials.htm; accessed June 30, 2017). The search was limited to studies about G. lucidum and G. frondosa that were published in the English language from January 1971 to April 2017.

\section{G. LUCIDUM AND G. FRONDOSA}

G. lucidum (Curtis) P. Karst. and G. frondosa (Dicks.) Gray are considered among the most important medicinal mushrooms in TCM and Japanese medicine. Several studies have examined the biological effects of mushrooms, principally by examining the stimulation of innate immune cells, such as monocytes, natural killer (NK) cells, and dendritic cells (DCs). The activity 
is generally considered to be caused by the presence of high molecular weight (HMW) polysaccharides in the mushrooms, although other constituents may also be involved [14].

\section{G. lucidum (Reishi)}

G. lucidum is a mushroom with many interesting bioactive compounds, but some taxonomic discrepancies prevent a clear definition of these compounds: many studies have been conducted to distinguish the European G. lucidum s.str. from the Asiatic (Chinese) mushroom. In China and Korea, G. lucidum is known as Ling-zhi, which means "spiritual power grass," while among the Japanese it is called Reishi or mannentake (" 10,000 years fungus"). Many authors accept that the Asiatic species is called Ling-zhi fungus and refer to the species as $G$. lingzhi Sheng H. Wu, Y. Cao \& Y.C. Dai [15]. G. lingzhi seems to have more triterpenic acids than G. lucidum s.str. [16-18]. The morphological characteristics of the species also differ [19-21]. G. lucidum s.str. basidioma is an annual, laccate, orange-red to dark reddish brown, generally laterally stipitate fungus; the pileus is fan shaped with the upper surface covered by a varnished crust at maturity. G. lucidum can be found worldwide in temperate and subtropical areas: it is common in Europe, the Americas (Argentina, Canada, and the U.S.), Africa (Kenya, Tanzania, and Ghana), and Asia (China, Japan, Korea, India, and other southeast Asian countries). It grows at the base of numerous hardwood plants, but rarely on coniferous ones, and mainly on dead wood. Because of its hard texture, it is not an edible mushroom but it is consumed in many ways, the simplest being in the form of teas or herbal teas. Nevertheless, thanks to its varied medicinal properties, it is extensively cultivated in many Asian countries, including China, Korea, and Malaysia. G. lucidum, which is a genus of polypore mushrooms, is a leader in terms of worldwide production of medicinal mushrooms.

\section{G. frondosa (Maitake)}

G. frondosa is another polypore that has a long history of medicinal use. It is commonly known by a variety of appellatives among English speakers, such as "hen of the woods," "ram's head," and "sheep's head"; in Japan, it is known as "Maitake," a name that means "dancing mushroom." The origin of the latter nickname is linked to the morphology of the species. The basidioma is large (up to $50 \mathrm{~cm}$ wide) and it grows every year in dense clusters at the base of trees. It has a compound structure and appearance, formed by a thick, whitish stipe and a common base from which the whole basidioma extend radially, branching repeatedly and supporting at its extremities individual petaloid basidiomata. The basidioma is constituted by a large number of imbricate, fan-shaped, confluent pilei [22]. The basidioma has a pleasant smell, and, in 1821, Gray defined this species as edible. It is appreciated for its culinary taste, mainly in Japan, where it is cultivated exclusively for this purpose. Only young basidiomata are edible, since, like all polypores, the fungus becomes tougher as it ages.

G. frondosa develops its basidioma around the base of living hardwoods, rarely on conifers. Fruiting can continue on dead trees or stumps. It spreads through submerged, rotting roots, by underground mycelium. It prefers oaks, though it also grows on other deciduous hardwoods such as beech, chestnut, elm, and maple [22]. It grows in northern temperate forests in North America (Canada and the northeastern U.S.), China, and Japan; it is uncommon in Europe.

\section{BIOLOGICALLY ACTIVE COMPOUNDS}

Medicinal mushrooms possess several biologically active compounds (Table 1): HMW compounds such as $\beta$-glucans (polysaccharides), glycoproteins, and low molecular weight (LMW) molecules such as quinones, sesquiterpenes, triacylglycerols, isoflavones, catechols, and steroids. Historically, each of these groups of mushroom metabolites was linked to a specific antitumor activity. For example, HMW compounds were believed to exert their antitumor activities by activating the immune response of the host organism, essentially by acting as immunomodulators with effects on both innate and adaptive immunity. LMW molecules were believed to act directly on tumor cells, regulating signal transduction pathways linked to cancer development, progression, and survival. However, increasing evidence shows that some polysaccharides (HMW) also exert direct actions on tumor cells, as observed for Maitake D-fraction (MD-fraction), an extract from the fruit bodies of Maitake that is very rich in proteoglycan $\beta$-glucans.

$\beta$-glucans from $G$. frondosa and G. lucidum constitute a heterogeneous group of glucose polymers; they consist of a backbone of $\beta$-1,3-linked $\beta$-Dglucopyranosyl units with $\beta$-1,6-linked side chains of varying distributions and lengths (Figure 1). $\beta$-1,3-glucans are major structural components of fungal cell walls (Figure 1). These molecular structures have been well identified by crystallographic assay [23]. However, their precise molecular mechanisms of action are still unclear. In particular, the immunomodulatory effects of $\beta$-glucans depend on the differences in the degree of branching, polymer length, and tertiary structures among $\beta$-glucans [24].

Ganoderic acid (GA) is a major triterpene isolated from G. lucidum in several isoforms ( $T, A, M e, H, D M$, and $X)$ and its antitumor activity is well-recognized. In addition, various sesquiterpenes also found with the same antitumor activity. GA effectively inhibits the proliferation of MCF-7 human BC cells via G1 cell cycle 
Table 1: primarly composition in bioactives substances of G. Lucidum and G. Frondosa

\begin{tabular}{lc}
\hline Substances & Ganoderma \\
\hline Water & $6.9 \%$ \\
Protein & $26.4 \%$ \\
& Fat \\
& $\begin{array}{c}\text { Acid, lignoceric acid, n-nonadecanoic } \\
\text { acid, Behenic acid, Tetracosanol, } \\
\text { Hentriacontane and Choline } \\
\text { triacylglycerols, }\end{array}$ \\
\end{tabular}

Food Fiber

Carbohydrate

Vitamins (mg/100g of product)

Terpenes

Inorganic
(mg/100g of
product)

Others

Substances

Water

Protein

Fat
Higher level of the RNA

Isoflavons

$43.1 \%$ principally Beta-D- Glucan $(25 \%)$

Vit B1 $3.5 \mathrm{mg}$, Vit B2 $17 \mathrm{mg}$, Vit B6 $0.7 \mathrm{mg}$, Choline $1150 \mathrm{mg}$, Niacin 62 $\mathrm{mg}$, Inositol $307 \mathrm{mg}$.

Ganoderic acids (Triterpenes)

Calcium 832 mg, Phosphorus 4150 mg, Iron 83 mg, Magnesium 1030 mg, Natrium 375 mg, Potassium 3590 mg,

G. Lucidum
$6.9 \%$
$26.4 \%$
acid, Palmitic Acid, Oleic
enic acid, n-nonadecanoic
ric Tetracosanol,
riacylglycerols

Grifola

$17,4 \%$

$20,3 \%$

3,5 Oleic acid, Stearic acid, Palmitic Acid, lignoceric acid, n-nonadecanoic acid, Behenic acid, Tetracosanol triacylglycerols,

$$
0,1 \%
$$

$46 \%$ principally Beta-D-

Glucan (20\%) which $20 \%$ is Maitake D-Fraction

Vit B1 $3.8 \mathrm{mg}$, Vit B2 $11 \mathrm{mg}$, Choline $850 \mathrm{mg}$, Niacin 73.5 $\mathrm{mg}$, Inositol $347 \mathrm{mg}$, betaine

$$
5.4 \mathrm{mg}
$$

\section{Various sesquiterpenes}

Calcium $820 \mathrm{mg}$, Phosphorus $4550 \mathrm{mg}$, Iron $86 \mathrm{mg}$, Magnesium 930 mg, Natrium 355 mg, Potassium 3390 mg.

Moderate level of RNA

High level of isoflavon

$$
\begin{gathered}
\text { G.Frondosa } \\
17,4 \% \\
20,3 \%
\end{gathered}
$$

4.5\% Stearic acid, Palmitic Acid, Oleic 3.5\% Oleic acid, Stearic acid, Acid, lignoceric acid, n-nonadecanoic Palmitic Acid, lignoceric acid, Behenic acid, Tetracosanol, acid, n-nonadecanoic acid, Hentriacontane and Choline Behenic acid, Tetracosanol triacylglycerols
Biological Activities

Higher nutritional functions

Oleic Acid, an inhibitor of histamine release.

The dietary fiber of fungus could lower cholesterol level, prevent atherosclerosis, constipation, diabetes.

Immunologic, antiinflammatory and anticancer effects involving several pathways via Dectin-1 receptor (see above).

Anti-androgenetic, G1 cell cycle blocking, inhibition of cells adhesion and migration.

Cyclo octasulfur, a strong inhibitor of histamine

release. Exceptional source of Potassium

RNA inducing interferon production in human cells which disrupts viral invasions

Mimic the Estrogen hormones in humans.

Biological Activities

Higher nutritional functions due aminoacid

Oleic Acid, an inhibitor of histamine release.

(Continued) 


\begin{tabular}{|c|c|c|c|}
\hline Substances & Ganoderma & Grifola & Biological Activities \\
\hline Food Fiber & $0.1 \%$ & $0,1 \%$ & $\begin{array}{c}\text { The dietary fiber of } \\
\text { fungus could lower } \\
\text { cholesterol level, prevent } \\
\text { atherosclerosis, constipation, } \\
\text { diabetes. }\end{array}$ \\
\hline Carbohydrate & $\begin{array}{l}43.1 \% \text { principally Beta-D- Glucan } \\
\qquad(25 \%)\end{array}$ & $\begin{array}{l}46 \% \text { principally Beta-D- } \\
\text { Glucan }(20 \%) \text { which } 20 \% \text { is } \\
\text { Maitake D-Fraction }\end{array}$ & $\begin{array}{c}\text { Immunologic, } \\
\text { antiinflammatory and } \\
\text { anticancer effects involving } \\
\text { several pathways via } \\
\text { Dectin- } 1 \text { receptor (see } \\
\text { above). }\end{array}$ \\
\hline $\begin{array}{l}\text { Vitamins }(\mathrm{mg} / 100 \mathrm{~g} \\
\text { of product) }\end{array}$ & $\begin{array}{l}\text { Vit B1 } 3.5 \mathrm{mg} \text {, Vit B2 } 17 \mathrm{mg} \text {, Vit B6 } \\
\text { 0.7-mg, Choline } 1.150 \mathrm{mg} \text {, Niacin } 62 \\
\text { mg, Inositol } 307 \mathrm{mg} .\end{array}$ & $\begin{array}{c}\text { Vit B1 } 3.8 \mathrm{mg} \text {, Vit B2 } 11 \mathrm{mg} \text {, } \\
\text { Choline } 850 \mathrm{mg} \text {, Niacin } 73 \\
\text { mg, Inositol } 347 \mathrm{mg} \text {, betaine } \\
5.4 \mathrm{mg}\end{array}$ & $\begin{array}{l}\text { General biochemical } \\
\text { activities }\end{array}$ \\
\hline Triterpenes & Ganoderic acids & sesquiterpenes & $\begin{array}{l}\text { Anti-androgenetic, G1 cell } \\
\text { cycle blocking, inhibition of } \\
\text { cells adhesion and migration }\end{array}$ \\
\hline $\begin{array}{l}\text { Inorganic } \\
\text { (mg/100g of } \\
\text { product) }\end{array}$ & $\begin{array}{l}\text { Calcium } 832 \text { mg, Phosphorus } 4150 \\
\text { mg, Iron } 83 \text { mg, Magnesium } 1030 \text { mg, } \\
\text { Natrium } 375 \text { mg, Potassium } 3590 \text { mg }\end{array}$ & $\begin{array}{l}\text { Calcium } 820 \text { mg, Phosphorus } \\
4.550 \mathrm{mg} \text {, Iron } 86 \mathrm{mg} \text {, } \\
\text { Magnesium } 930 \mathrm{mg} \text {, Natrium } \\
355 \mathrm{mg} \text {, Potassium } 3390 \mathrm{mg} \text {. }\end{array}$ & $\begin{array}{l}\text { Cyclo octasulfur, a strong } \\
\text { inhibitor of histamine } \\
\text { release }\end{array}$ \\
\hline \multirow[t]{2}{*}{ Others } & Higher level of the RNA & Moderate level of RNA & $\begin{array}{l}\text { RNA inducing interferon } \\
\text { production in human } \\
\text { cells which disrupts viral } \\
\text { invasions }\end{array}$ \\
\hline & Isoflavons & High level of isoflavon & $\begin{array}{l}\text { Mimic the Estrogen } \\
\text { hormones in humans. }\end{array}$ \\
\hline
\end{tabular}

Source: //:www.mdidea.net (accessed June 30, 2017).

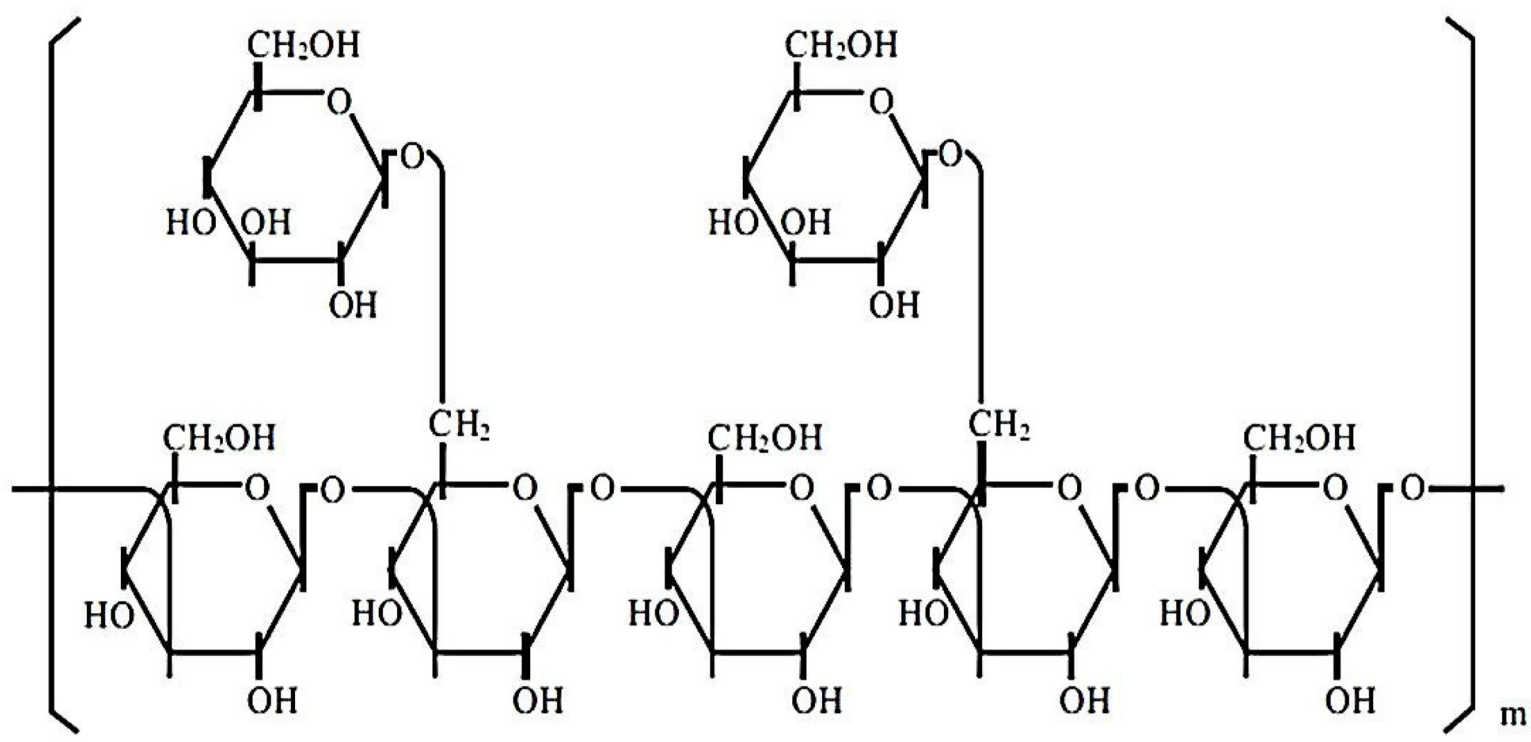

Figure 1: The polymeric structure of $\boldsymbol{\beta}$-glucans. These molecules are constituted by heterogeneous groups of glucose polymers, consisting of a backbone of $\beta$ - $(1,3)$-linked $\beta$-D-glucopyranosyl units with two $\beta-(1,6)$ linked side chains every five $\beta$ - $(1,3)-$ linked backbone residues. 
arrest. In addition, it significantly decreases the protein levels of cyclin-dependent kinase (CDK) 2, CDK6, cyclin $\mathrm{D} 1, \mathrm{p}-\mathrm{Rb}$, and c-Myc in MCF-7 cells. GA also induces DNA fragmentation and cleavage of PARP, which are characteristic of apoptosis and decrease the mitochondrial membrane potential in MCF-7 cells [25]. GA has antiandrogenic activity, which leads to its therapeutic benefits in prostate cancer, and regulates osteoclastogenesis by suppressing the expression of c-Fos and nuclear factor (NF) of activated $\mathrm{T}$ cells c1 [26]. Additionally, GA inhibits proliferation and cell aggregation of HCT-116 cells (a human colon carcinoma cell line) by inhibiting the adhesion of HCT-116 cells to the extracellular matrix in a dose-dependent manner. GA inhibits the nuclear translocation of NF- $\kappa \mathrm{B}$, which leads to downregulated expression of matrix metalloproteinase (MMP)-9, inducible nitric oxide synthase (iNOS), and urokinase-type plasminogen activator [27].

\section{IMMUNOMODULATING PROPERTIES}

The functioning of the immune system is critically engaged in the progression of tumors, and immunotherapy is the foremost strategy for cancer treatment. Cancer therapy highlights the role of B and T lymphocytes, DCs, NK cells, and mononuclear phagocyte cells. Mushrooms exhibit interesting immune-regulating properties that may be useful in cancer management. Successful immunotherapy requires both the increase in tumorspecific immunity and the reversal of tumor-associated immune suppression (Figure 2).

Ingestion of oral $\beta$-glucans in medicinal mushrooms has been found to activate various immune system components, including macrophages, NK cells, DCs, and $\mathrm{T}$ helper lymphocytes, which affects tumor cell viability and potentiates the release of various mediators including lymphokines and interleukins (ILs) [28]. Mammalian digestive enzymes do not digest $\beta$-glucans; therefore, it is unclear how soluble $\beta$-glucans can be adsorbed in the GI tract. Rice et al [29] demonstrated that 3 fluorescently labeled, soluble $\beta$-glucans, which varied in molecular weights and structures, were rapidly absorbed from the GI tract into systemic circulation and detected in plasma after oral administration in rats. Sandvik et al [30] showed that a specific and minute fraction of the orally administered soluble $\beta$-glucan translocated to circulation. What is known is that $\beta$-glucans are not biomolecules expressed on mammalian cells and, therefore, are recognized as

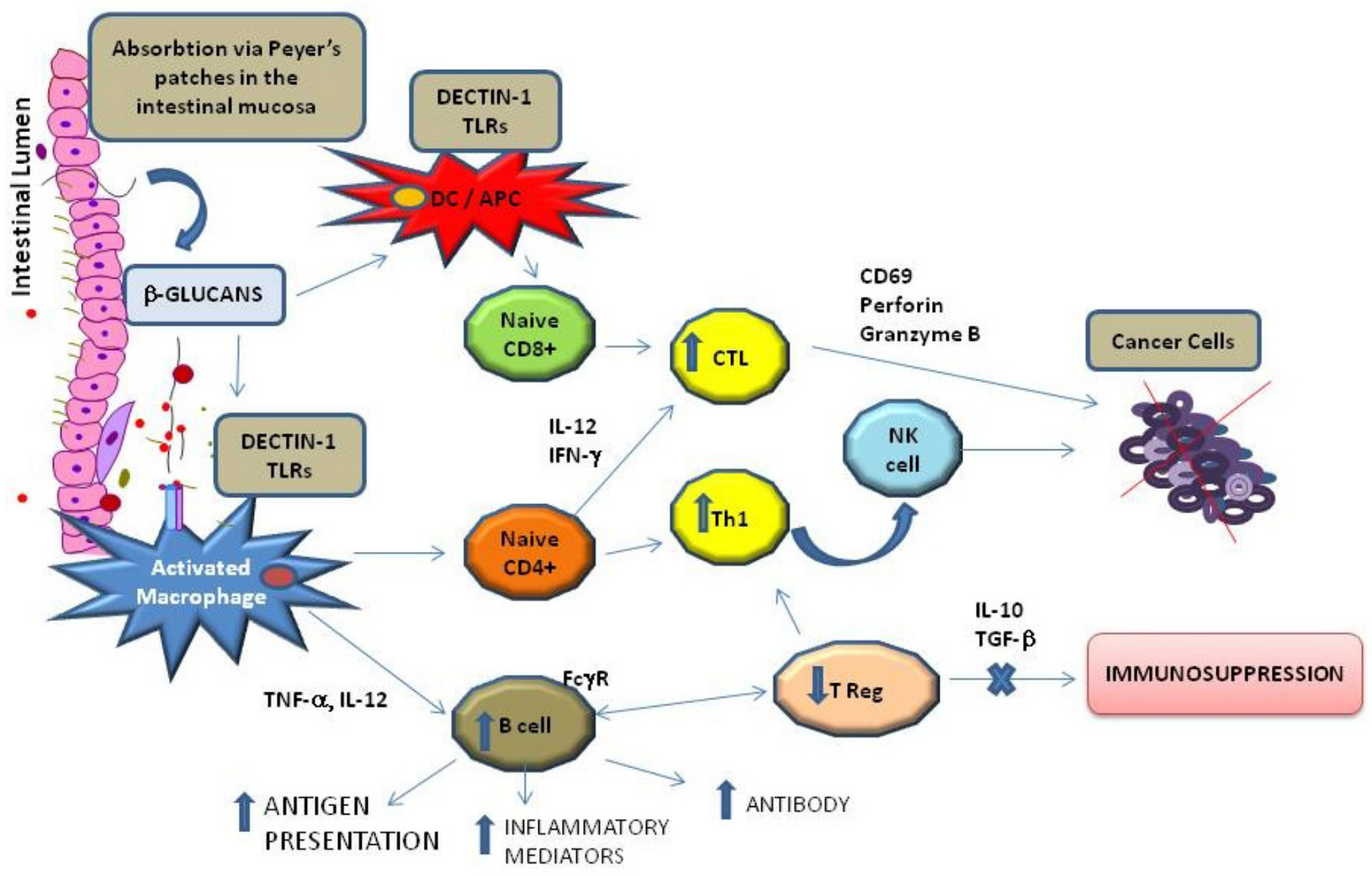

Figure 2: Schematic immunomodulating effect of b-glucans after absorption via intestinal mucosa. b-glucans can directly activate macrophages and Dendritic Cells (DCs) in the Peyer's patches and can induce both, helper T cells (Th) and tumor-specific cytotoxic $\mathrm{T}$. In addition, Fc gamma Receptor (FcgR) provides a critical link between specific humoral responses and cytotoxic T cells Lymphocyte (CTCL). 
pathogens, similar to viruses, fungi, mushrooms, yeast, algae, lichens, plants, and some bacteria.

Masuda [31] described that the first effect of orally administered MD-fraction, a highly purified soluble $\beta$-glucan, is observed in the gut-associated lymphoid tissue (GALT). Orally administered MD-fraction is taken up by antigen presenting cells (APCs) such as DCs and macrophages present in the intestinal mucosa in Peyer's patches (PPs). MD-fraction, via a C-type dectin-1 pathway, directly induces DC maturation. In this way, the intestinal mucosa could act as a portal for antigen uptake; $\beta$-glucans may then be transported to systemic circulation from the intestinal lumen to the lymphoid tissues. The captured MD-fraction is then transported to the spleen, thereby inducing the systemic immune response as demonstrated in tumor-bearing mice [31].

Maitake $\alpha$-glucan YM-2A isolated from $G$. frondosa has been characterized as a highly $\alpha-1,6$-branched $\alpha-1,4$ glucan. Interestingly, YM-2A is more resistant to digestive enzymes than are amylopectin and rabbit liver glycogen: orally administered YM-2A can activate macrophages and DCs in PPs in GALTs. The immunomodulatory effect of YM-2A makes it a promising candidate as an oral therapeutic agent in the translational and clinical research of antitumor immunotherapy [12].

Orally administrated $\beta$-glucan is recognized by APCs through multiple interactions with pattern recognition receptors (PRRs), such as the C-type lectin receptor dectin- 1 and the complement receptor type 3 [32-36]. Interestingly, the agonists for PRRs, such as the dectin-1 receptors and the toll-like receptors (TLRs), are potent adjuvant treatments for infectious diseases and have been used as immunotherapeutic agents in cancer patients.

Several studies have demonstrated that DCs are functionally defective in tumor-bearing hosts. MDfraction can directly activate macrophages and DCs and can induce both helper T cells (Th) and tumor-specific cytotoxic $T$ cells to inhibit tumor cell growth [37]. The novel polysaccharide Maitake Z-fraction (MZF), a heteropolysaccharide isolated by Masuda et al, was found to induce DC maturation and antigen-specific Th1 response by enhancing DC-produced IL-12 in murine colon cancer [38]. The authors suggested that MZF could be a potential effective adjuvant therapy to enhance immunotherapy using DC-based vaccination [38].

A proteoglycan bioactive fraction isolated from the fruiting body of G. lucidum (GLIS) has been found to strengthen the building of the immune system in mouse spleen lymphocytes, resulting in a 3- to 4-fold increase in the percentage of B cells [39]. The authors suggested that GLIS is a new B cell-stimulating factor [39].

In a non-randomized human clinical trial, 36 patients with advanced (stage II-IV) breast, liver, or lung cancer were administered a combination of oral MD-fraction and Maitake tablets. The treatment demonstrated immuneenhancing properties such as increased numbers of IL-2 and CD4+ cells [40]. Furthermore, it was suggested that $\beta$-glucans can cooperate with antitumor monoclonal antibodies that are used for cancer immunotherapy [41]. In fact, when the constant region $(\mathrm{Fc})$ of an immunoglobulin interacts with receptors for the $\mathrm{Fc}$ domain of Immunoglobulin $\mathrm{G}$ ( $\mathrm{Fc}$ gamma $\mathrm{R}$ [Fc $\gamma \mathrm{R}]$ ) on leukocytes, a variety of biological responses are triggered: phagocytosis, enhanced antigen presentation, release of inflammatory mediators, and antibody-dependent cellular cytotoxicity [28]. Therefore, Fc $\gamma \mathrm{R}$ provides a critical link between specific humoral responses and cellular immunity, and $\beta$-glucans were reported to enhance the expression of Fc $\gamma \mathrm{R}$ and the activation of complements [41].

The induction of the capacity of native antitumor immune responses is hampered by the immunosuppressive nature of the tumor microenvironment, which is mediated by myeloid-derived suppressor cells and regulatory $\mathrm{T}$ cells. The tumor microenvironment also inhibits DC maturation through the secretion of IL-10 and transforming growth factor beta (TGF- $\beta$ ). Cancer cells resist and adapt to inhibit the immune system by releasing immunosuppressive mediators (prostaglandin E2 [PGE2], TGF- $\beta$, IL-10, and vascular endothelial growth factor [VEGF]) against immune surveillance. G. lucidum and G. frondosa polysaccharides counteract this immune inhibition and control tumor formation by suppressing cell proliferation and activation of CD69 expression, perforin, and granzyme B production [42].

In summary, the therapeutic response to orally administered $\beta$-glucans in vivo is associated with (i) induced systemic tumor-antigen specific $\mathrm{T}$ cell response via dectin-1-dependent activation of DCs, (ii) increased tumor-infiltrating, tumor antigen-specific $\mathrm{T}$ cells in the tumor, and (iii) decreased tumor-caused immunosuppressive cells such as regulatory $\mathrm{T}$ cells and myeloid-derived suppressor cells [31].

\section{ANTI-INFLAMMATORY PROPERTIES}

Mushrooms have been well known for many years in medicine for their beneficial properties based on the modulation of several cytokines and ILs, as demonstrated in both preclinical and clinical studies [9]. Inflammation is a natural process that, when it becomes persistent and of low grade in some tissues, can lead to biochemical reactions in cells activating oncogenes and metabolic changes such as insulin resistance and over-activation of receptor tyrosine kinases (RTKs). In common tumors like breast and prostate cancers, there are small microareas in tissues composed of cancer cells associated with adipocytes, macrophages, and fibroblasts that work together to create a tumor microenvironment that is rich in growth factors, microRNA, and cytokines - all with pro-inflammatory properties that promote survival and chemoresistance [9]. 
$\beta-1,3-$ and $\beta-1,6-\mathrm{D}$-glucans extracted from G. lucidum are able to decrease inflammation in a concentration- and time-dependent manner. An Indian study demonstrated that G. lucidum at a dose of $100 \mathrm{mg} /$ $\mathrm{kg}$ body weight showed anti-inflammatory activities comparable to those of diclofenac at a dose of $10 \mathrm{mg} /$ $\mathrm{kg}$ body weight, achieving a roughly $50 \%$ reduction in inflammation in mouse models. More recently, it was demonstrated that ethanol or DMSO extracts of G. lucidum are able to decrease IL-8, IL-6, MMP-2, and MMP-9 secretion by triple-negative human $\mathrm{BC}$ cells (i.e., the most aggressive cancer type) exposed to lipopolysaccharides (LPS) by approximately $52 \%, 50 \%, 42 \%$, and $50 \%$, respectively, compared to untreated cancer cells [9] (Figure 3). These effects are linked to the downregulation of NF- $\mathrm{KB}$ signaling induced by G. lucidum. In fact, it was observed that GA C1, one of the most important bioactive compounds present in this mushroom, is able to decrease tumor necrosis factor (TNF)- $\alpha$, interferon (IFN)- $\gamma$, and IL-17A secretion in inflamed colonic cells derived from patients affected by Crohn's disease [43]. From a molecular point of view, many bioactive constituents of G. lucidum have shown potent anti-inflammatory effects; in fact, it has been shown to inhibit LPS-stimulated nitric oxide production by macrophages and downregulated mRNA gene expressions of pro-inflammatory cytokines including iNOS, IL-1, and TNF- $\alpha$ in a dose-dependent manner with a marked stimulation of IL-10, a well-known anti-inflammatory cytokine in dopaminergic neurons and microglia [44] (Figure 3).

A recent study demonstrated that $G$. frondosa extract decreased TNF- $\alpha$ levels in rats that received captopril, a common inducer of inflammation and insulin resistance, which suggests a lessening of the inflammatory state in these rats due, most probably, to the $\beta$-glucans, flavonoids, ascorbic acid, and $\alpha$-tocopherol residues present in the extract of the mushroom [45]. Another paper revealed the abilities of $G$. frondosa to enhance INF activity in patients with invasive bladder cancer [46].

The main component of $G$. frondosa extract is a water-soluble glucan/protein (ratio 80:20-99:1) complex [47] that is able to ameliorate colon inflammation by suppressing production of TNF- $\alpha$ and its signaling through $\mathrm{NF}-\mathrm{\kappa B}$, which leads to the expression of pro-inflammatory chemokines in HT-29 human colon cancer cells with U937 human monocytic cells (MCP-1 and IL-8).

\section{DIRECT ANTICANCER ACTIVITY}

The anticancer effects of G. frondosa and G. lucidum have been demonstrated mainly in in vitro and in vivo experiments (Figure 4), but a very limited number of studies have been conducted in humans. In addition to the intrinsic role of inflammatory processes in cancer's etiogenesis, progression, and biology, it is essential to consider a holistic point of view in terms of research, as well as clinical practices. From this perspective, mushrooms could be useful during CT or RT, as well as integrated into the diet in the form of supplements, as part of cancer care and management. In fact, several flavonoids, carbohydrates, fatty acids, and glucans derived by mushrooms affect the gene expression and biochemical functions of several oncogenes and tumor suppressors in BC cells [48].

G. lucidum modulates the signaling of cancer cells by inhibiting NF- $\mathrm{KB}$ nuclear translocation RASmitogen-activated protein kinase (MAPK) activation and apoptosis processes. In particular, GA, a triterpene isolated from G. lucidum, strongly inhibits the activation of transmembrane surface receptors (RTKs) [49], which modulate intracellular downstream signals responsible for cell adhesion, proliferation, migration, apoptosis, and metabolism in various cancer cells. Specifically,
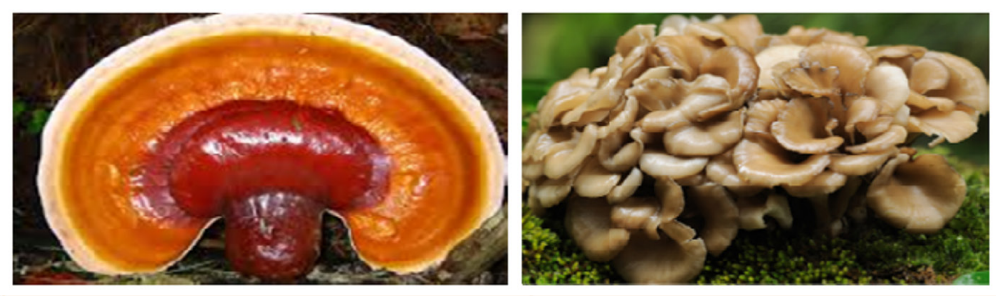

\begin{tabular}{|c|c|c|}
\hline Down regulation & $\begin{array}{l}\text { IL-8, IL-6, MMP-9, } \\
\text { NO, TNF- } \alpha \text {, IFN- } \gamma \text {, } \\
\text { IL-17, IL-1 }\end{array}$ & $\begin{array}{l}\text { NF-кB, TNF- } \alpha \text {, } \\
\text { MCP-1, IL-8 }\end{array}$ \\
\hline Up regulation & IL-10, IL-2 & \\
\hline
\end{tabular}

Figure 3: Principal inflammation-involved biomolecules affected by curative mushrooms: G. lucidum (left), and G. frondosa (right). 
50 isoforms of GA were studied in relation to specific inhibition of RTKs such as insulin receptor (IR), insulin-like growth factor (IGFR), VEGFR1, VEGFR2, and estrogen receptor in liver cancer cells (Figure 4). Specifically, G. tsugae methanol extract was shown to inhibit epidermal growth factor receptor (EGFR) and VEGF, which are important for tumor angiogenesis and growth in human epidermoid carcinoma cells in vitro and in vivo [50].

G. lucidum has also been evaluated in colorectal cancer in vitro and in vivo, and in the most common lung cancer biotype. Specifically, G. lucidum polysaccharides (GLPS), a water extract of sporoderm broken spores, significantly inhibited the viability of HCT-116 colorectal cancer cells in a dose- and time-dependent manner. GLPS inhibited the functions of RTKs, such as PS-F2, and played a key role in the modulation of MAPKs, JNK, p38, ERK, and NF- $\mathrm{B}$, which are critical for activation of TNF- $\alpha$ in cancer signaling [51]. Furthermore, GLPS stimulated TNF- $\alpha$ and immunomodulatory activities in lung cancer patients. Oral administration of G. lucidum extracts suppressed lung cancer tumor growth in mice and suppressed the activation of PKB (Akt), mechanistic target of rapamycin (mTOR), S6 kinase, and 4E-BP1 in lung cancer cells [52].

The most important preclinical studies of the anticancer effects of Maitake were performed to evaluate MD-fraction activities: it has direct antitumor activity in LM3 murine mammary adenocarcinoma cells, thus preventing oncogenesis and metastasis in human cancer cells [13]. The antitumor effects of MD-fraction have been attributed mainly to its immunostimulatory capabilities, as previously reported, as well as to direct antiproliferative and cytotoxic effects in human cancer cells, including prostate [53], bladder, liver, brain, blood (leukemia), and breast cells [54]. Interestingly, MD-fraction decreases

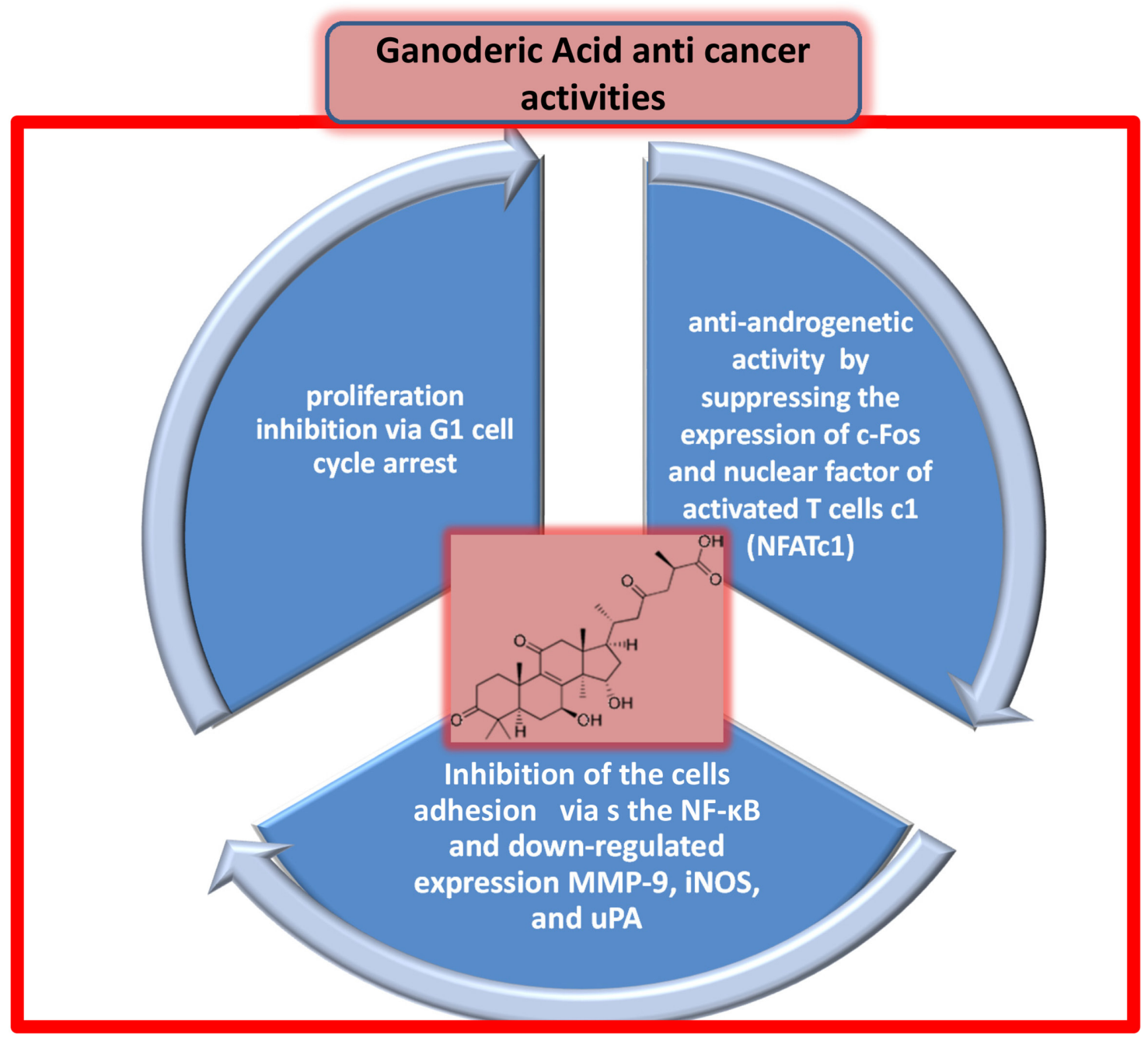

Figure 4: Direct anticancer activities of triterpenes ganoderic acid (chemical structure shown in pink inset). 
Table 2: Clinical information about how could be recommended the use of G. lucidum and G. frondosa in hormone dependent and triple negative breast cancer patients

\begin{tabular}{lcc}
\hline Mushroom & Breast cancer (hormone dependent) & Breast cancer (triple negative) \\
\hline G. lucidum & +++ & $?$ \\
G. frondosa & + & $?$ \\
\hline
\end{tabular}

+++ strongly recommended; + recommended, but need to watch out for possible depressive immune effects in these patients;? no clinical trials found in literature but several mouse models are strongly promising.

cell viability, increases cell adhesion, and reduces the migration and invasion of human lung cancer cells, generating less aggressive cell behavior [13].

Clinically, Maitake may have the potential to decrease the size of cancers of the lung, liver, and breast. Specifically, in a non-randomized study, a combination of MD-fraction and whole Maitake powder, given alone without any anticancer drugs, exerted anticancer activities in 22- to 57-year-old cancer patients with stage II-IV disease (clinical trial based on different types of cancer). Cancer regression or significant symptom improvement was observed in $58.3 \%$ of liver cancer patients, $68.8 \%$ of $\mathrm{BC}$ patients, and $62.5 \%$ of lung cancer patients [55]. On the basis of this information (Table 2), mushrooms can be considered as part of $\mathrm{BC}$ patient management to decrease side effects related to CT and increase QoL. Further clinical studies are strongly recommended because, for example, MD-fraction of G. frondosa could exert opposite dose-dependent effects under the same immunologic parameters [56]. However, it is interesting that daily oral administration of $5 \mathrm{mg} / \mathrm{kg}$ of $G$. frondosa in these patients was associated with the most prominent immunological changes with increasing productions of IL-2, IL-10, TNF- $\alpha$, and IFN- $\gamma$ by subsets of T cells.

\section{MECHANISM OF ACTION AND PUTATIVE ANTICANCER FUNCTION OF $\beta$-GLUCANS IN HUMAN BREAST CANCER CELLS IN VITRO}

In a human BC MCF-7 cell model, it was demonstrated that $\beta$-glucans can influence the expression of several oncogenes and tumor suppressor genes and, thus, might be able to contrast the BC phenotype developments. Since the cellular mechanisms of actions of $\beta$-glucans that influence growth pathways by blocking the $E 2 F$ signals are not yet clarified, we could only describe the effective genotype/phenotype effect mediated by diverse molecular mechanisms, which are postulated below (Table 3 and Figure 5) [13]:

a. Inducing apoptosis through activation of BAK1, BCLAF1, RASSF2, FADD, SPARC, and BCL2L13 genes and by downregulating PI3K-AKT signaling. The BAK1 gene product primarily enhances apoptotic cell death after MD-fraction [54]. Activated BAK1 proteins oligomerize at the mitochondrial membrane and cause the release of several mitochondrial factors, such as cytochrome C, which, in combination with pro-caspase 9 and peptidase activating factor 1 interacting protein, starts the apoptotic cascade.

b. Blocking neoplastic cell proliferation through activation of CDK inhibitor 1B (alias p27). It is known that an increase in p27 gene expression is associated with cell growth arrest, cell differentiation, and apoptotic pathways, but its low expression is related to stimulation of cell proliferation and has been demonstrated to have prognostic implications in early stages of mouse mammary pre-neoplasia [57]. Also, $\beta$-glucans inhibit tumor cell protein, stimulating the over-expression (4.70-fold) of the retinoblastoma binding protein (RBBP) 4 gene in $\mathrm{BC}$ cells [13]. The RBBP4 gene encodes an integral component of transcriptional silencing co-repressor complexes and it is specifically involved in transcriptional repression of E2Fresponsive genes. The over-expression of the RBBP4 gene in $\mathrm{BC}$ cells blocks the RB-E2F protein complex formation, inhibiting tumor cell growth and proliferation pathways [13]. In addition, IGFR binding protein (IGFRBP)-7 expression is inversely correlated with disease progression in BC cell line MDA-MB-468. These results suggest that the growth of $\mathrm{BC}$ could be controlled by the forced expression of the IGFBP-7 protein in human BC cells and xerografted tumors [58]. In addition, it was demonstrated that the upregulation of phosphatase and tensin homolog/ p27 complex allowed cell cycle arrest in the G1 phase [59].

c. Blocking cell migration and invasion by increasing the gene expression and activity of $\alpha 2$ integrin (ITGA2) in BC compared to normal breast tissue [60]. Reduced ITGA2 gene expression is highly associated with disease progression and clinical outcomes of BC [61, 62]. On the basis of these findings, we hypothesize that over-expression of ITGA9 and ITGA2 could be involved in the antitumor effects of MD-fraction. In addition, the antitumor activity was tested in MCF-7 BC cells and a 1.47-fold reduction in the expression of the CD44 gene was observed, suggesting that MMP-9 cannot bind the CD44 receptor on the cell surface. Consequently, the 
Table 3: Synopsis of the Putative Anticancer Function of $\beta$-Glucans

\begin{tabular}{|c|c|c|c|}
\hline Action & ${ }^{\#}$ Interfering pathway & Annotation & Ref. \\
\hline Inducing apoptosis & $\begin{array}{c}\text { Through activation of } B A K 1 \text {, } \\
B C L A F 1, R A S S F 2, F A D D, S P A R C, \\
\text { and } B C L 2 L 13 \text { genes and by } \\
\text { downregulated PI3K-AKT signalling }\end{array}$ & $\begin{array}{l}\text { The cancer prevention activity } \\
\text { primarily depend on the ability of any } \\
\text { agents to increases the activation of } \\
\text { pro-apoptotic genes which will lead the } \\
\text { death of precancerous cells. }\end{array}$ & {$[54]$} \\
\hline $\begin{array}{l}\text { Blocking neoplastic } \\
\text { cells proliferation }\end{array}$ & $\begin{array}{l}\text { Increases the expression of cyclin- } \\
\text { dependent kinase }(C D K) \text { inhibitor 1B } \\
\text { and PTEN/ciclin D1. }\end{array}$ & $\begin{array}{l}\text { Upregulation and downregulation of } \\
\text { the cell cycle genes is fundamental for } \\
\text { blocking proliferation of neoplastic } \\
\text { cells. }\end{array}$ & {$[57-59]$} \\
\hline $\begin{array}{l}\text { Blocking cell } \\
\text { migration and } \\
\text { invasion }\end{array}$ & $\begin{array}{l}\text { Increases expression of } \alpha 2 \text { integrins } \\
(I T G A 2) . \text { Downmodulation of } C D 44 / \\
M M 9 \text { complex }\end{array}$ & $\begin{array}{c}\text { Due to ITGA2 upregulation } \\
\text { and CD44 downmodulation after } \\
\text { Maitake treatment, thus blocking } \\
\text { tumor cell survival, metastasis, and } \\
\text { arteriogenesis in tumoral MCF-7 cells. }\end{array}$ & {$[60-62]$} \\
\hline $\begin{array}{l}\text { Inducing sensitivity } \\
\text { to chemotherapy }\end{array}$ & $\begin{array}{c}\text { By reducing the expression of ATP- } \\
\text { Binding Cassette grouping } 2 \text { (ABCG2). } \\
\text { Over expression of SPARC }\end{array}$ & $\begin{array}{l}\text { High level of ABCG } 2 \text { transmembrane } \\
\text { protein extrude the high quantity of } \\
\text { drugs from the cells, reducing their } \\
\text { anticancer activity. } \\
\text { SPARC interferes with the interaction } \\
\text { between caspase } 8 \text { and Bcl } 2 \text { to } \\
\text { resensitize chemo resistant tumors and } \\
\text { enhance their regression in vivo. }\end{array}$ & {$[63]$} \\
\hline $\begin{array}{l}\text { Reducing the } \\
\text { oxidative stress }\end{array}$ & Increasing gene expression of SOD2 & $\begin{array}{l}\text { Mutant SOD2 drives tumor progression } \\
\text { and metastasis by loss mitochondrial } \\
\text { anti-oxidative stress functions. }\end{array}$ & {$[64,65]$} \\
\hline
\end{tabular}

\# referred to gene expression profile studies on cancer cell lines.

CD44/MMP9 complex cannot form, thus blocking tumor cell metastasis and arteriogenesis in the MCF-7 cell line [13].

d. Inducing multidrug sensitivity by reducing the expression of ATP-binding cassette $(\mathrm{ABC})$ group 2 (ABCG2, alias BPRP) [13]. Cells become resistant to chemotherapy through the expression of $\mathrm{ABC}$ transporters that, using ATP, extrude different substrates (e.g., cytostatic drugs) out of tumor cells. The ABC transporter $\mathrm{BC}$ resistant protein (ABCG2 or BPRP) is a major determinant of the multidrug resistance phenotype. Cancer cells that express low levels of multidrug transporters are more sensitive to CT. In addition, it was found that MDfraction significantly induces the over-expression (5.45fold) of osteonectin, also known as secreted protein acidic and rich in cysteine (SPARC) gene, in MCF-7 cells [13]. These findings suggest that increasing the sensitivity to CT might be useful as a complementary therapeutic approach for the subset of triple-negative $\mathrm{BC}$ patients who over-express SPARC, as postulated previously [63].

e. Reducing the oxidative stress by increasing the gene expression of superoxide dismutase 2 (SOD2). SOD2 is the key enzyme in mitochondria that protects cells from oxidative DNA damage caused by free radical production. Levels of SOD2 are reduced in many diseases, including cancer [64]. Furthermore, a possible mechanism by which mitochondrial oxidative stress contributes to tumor initiation and progression is an increase in mutation rate that confers putative selection of tumor cell clones with a growth advantage [65].

Still, the exact mechanisms and correlations among these genes and $\beta$-glucan is not yet fully understood in humans. However, studies investigating these relationships are crucial for understanding how a nutrigenomic agent and/or CAM can be transformed into a therapeutic agent for cancer [3].

\section{MICROBIOTA, BREAST CANCER, AND G. LUCIDUM}

Humans are colonized by various commensal microorganisms, which form the human microbiome. The community of microorganisms that exist within the GI ecosystem is termed the "GI microbiota." To understand the importance of GI microbiota in health and disease, as 
well as its ability to induce carcinogenesis, it is crucial to appreciate the complexity of its composition, as well as the relationship between microorganisms and host. The adult GI system harbors approximately 100 trillion resident microbes, which represent approximately 10 times the number of cells in the human body $[66,67]$. The human GI microbiota is a dynamic and complex ecosystem that contains several different species that cooperate with each other for mutual gains under homeostasis [68]. Microbiota dynamics and complexity increase after birth, reaching the highest points in early adulthood and then remaining quite stable over time (Figure 6).

However, the microbiota can be affected by diet and other environmental factors such as antibiotic treatment, pathogen exposure, cold stress, or perturbations of diurnal rhythms [69-71] (Figure 7). Changes in the GI microbiota stability and dynamics have been associated with several diseases, including type II diabetes, obesity, fatty liver disease, irritable bowel syndrome, inflammatory bowel diseases, and even certain cancers.

The GI microbiota performs essential functions in the maintenance of health, including protective, structural, and metabolic roles (Figure 8). The GI microbiota influences the development of the intestinal barrier and its functions, and it exerts positive stimulatory effects on the intestinal innate and adaptive immune systems, which include the development of the intestinal mucous layer and lymphoid structures, differentiation of immune cells, and production of immune mediators [72]. The link between cancer and microorganisms is well established, and as much as $20 \%$ of the global cancer burden has been estimated to be influenced by microorganisms [73]. The mechanisms that contribute to dysbiosis and to alterations in the microbial environment are not yet understood. Host-derived immune and inflammatory responses are important driving forces that shape the composition of the microbial community and, when altered, may contribute to dysbiosis. It is already documented that GI microbiota affects carcinogenesis through the release of carcinogenic molecules, such as genotoxins, and through the production of tumor-promoting metabolites, such as ammonia, amines, phenols, sulfides, and nitrosamines [74-76], which induce responses to DNA damage. It has been suggested that specific low-abundance microorganisms,

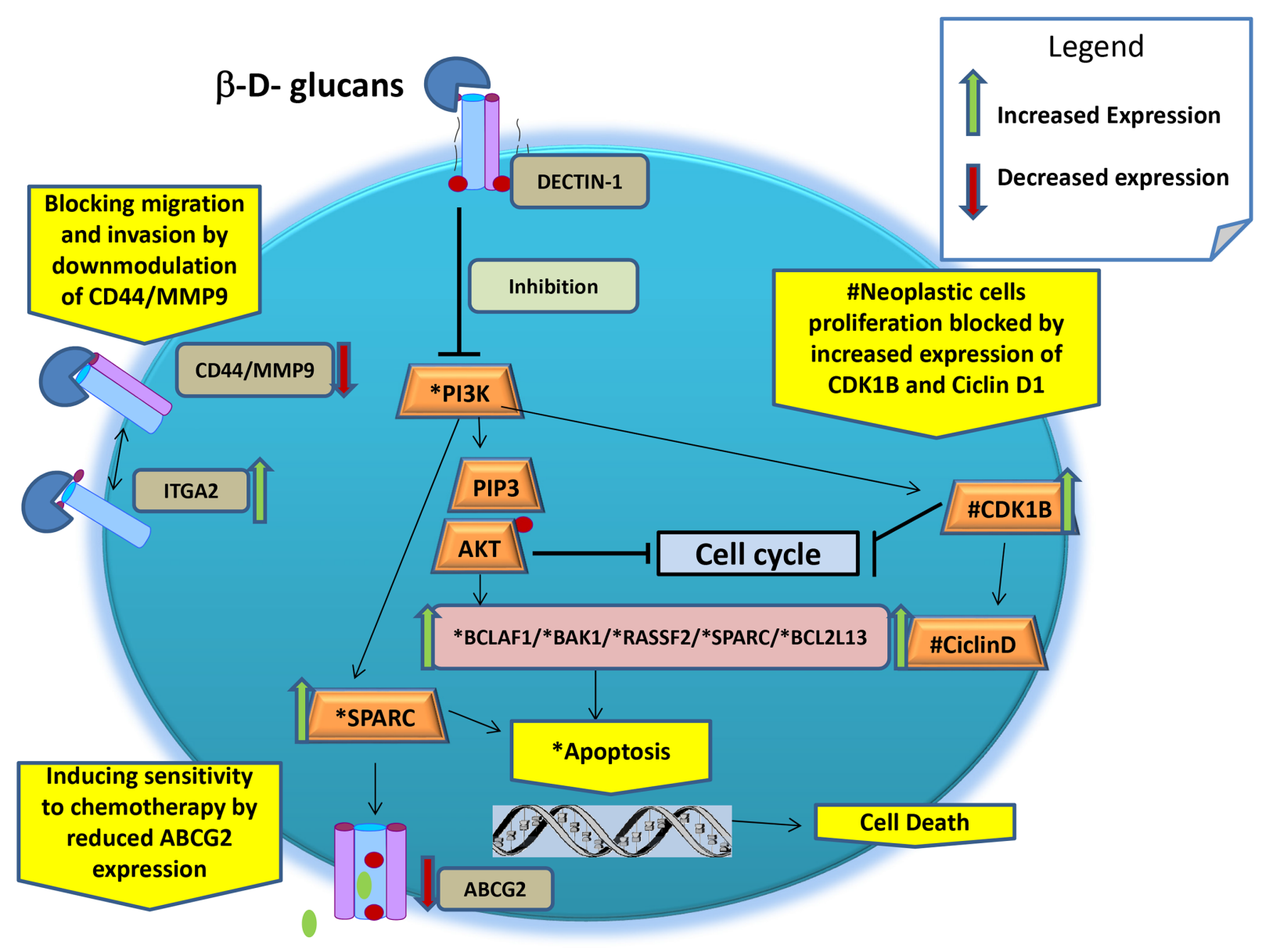

Figure 5: Schematic representation of main putative anticancer cellular mechanisms of $\beta$-glucans.

* molecules involved directly and indirectly in the apoptosis.

\# molecules involved directly and indirectly in the blocking of proliferation. 
termed 'keystone pathogens,' may further amplify dysbiosis in disease states by exerting dominant effects on bacterial composition [77]. It is clear that bacterial pathogens participate in more than just colorectal carcinogenesis; they affect the development incidence and tumor progression of extra-intestinal cancers, including $\mathrm{BC}[78,79]$. Recent studies demonstrated that acetate, one of the main SCFA produced by GI microbiota metabolism, can support the growth of several human cancer types, including $\mathrm{BC}[80,81]$. However, to date, results have not provided a clear understanding of the precise roles that acetate oxidation play in carcinogenesis and cancer progression.

Epidemiological studies have suggested that repeated exposure to broad-spectrum antibiotics induces changes in the GI microbiota, which may affect the metabolism of sex hormones, such as estrogens, thereby influencing the risk of $\mathrm{BC}[82,83]$. The influence of GI microbiota on $\mathrm{BC}$ development, especially in postmenopausal women, is associated with immune regulation, obesity status, and elevated levels of endogenous or circulating estrogens [84-86] through enterohepatic circulation; large differences in these factors exist among individuals [83, 86-89]. Several host factors, including age, ethnicity, antibiotic use, diet, and alcohol consumption, may exert selective pressure on GI microbiota, especially on bacterial species with $\beta$-glucoronidase activity (constituents of the "estrobolome") [90]. In particular, bacterial species belonging to Bacteroidetes and Firmicutes phyla possess distinct $\beta$-glucuronidase genes [91-93] that are able to deconjugate the estrogens excreted in the bile, leading to estrogen reabsorption into circulation. This increased total estrogen burden potentially contributes to the risk of development of hormone-driven malignancies such as BC.

Goedert et al. [94] compared GI microbiota profiles and levels of estrogens in urine of postmenopausal $\mathrm{BC}$ patients and control patients. They discovered differences between the groups that underscore the relationship between the GI microbiota and hormonedriven carcinogenesis. The active role of GI microbiota in breast carcinogenesis should be investigated further to better elucidate the link between the GI microbiome and estrogen as a driver for $\mathrm{BC}$ in order to develop novel therapeutic interventions.

The GI microbiota continue to yield insight into the basic mechanisms of carcinogenesis and several approaches could be used to modulate the carcinogenic potential of the GI microbiota. One strategy could be to push the GI microbiota balance towards richer composition of beneficial bacteria, which can be achieved by alternative approaches such as the use of medicinal mushrooms. There is evidence of potential health benefits of mushroom extracts for their antibacterial, anti-inflammatory, antiviral, antiatherosclerotic, antidiabetic, and anticancer activities $[95,96]$. Traditionally, a high number of fungal species have been used as nutraceuticals; among them, one of the most intriguing medicinal mushrooms is the G. lucidum, which has been used for centuries to promote health [97]. Mushroom polysaccharides, as well as the products of their partial hydrolysis, are considered prebiotics [98100], since they may affect the GI tract, binding TLRs expressed in the host [101]. Recently, scientific evidence revealed that G. lucidum modulates the composition of GI microbiota in different disorders, such as obesity and

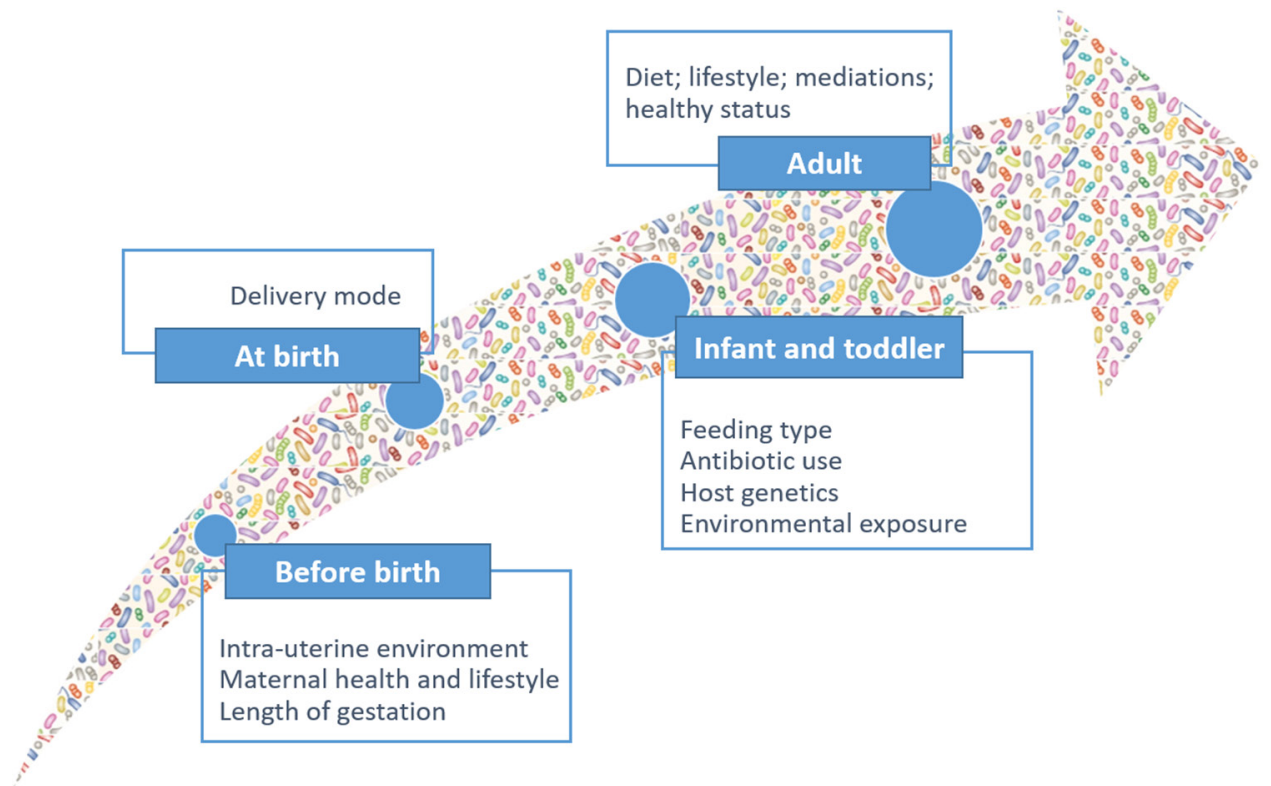

Figure 6: Microbiota dynamics and complexity from birth to adult. 


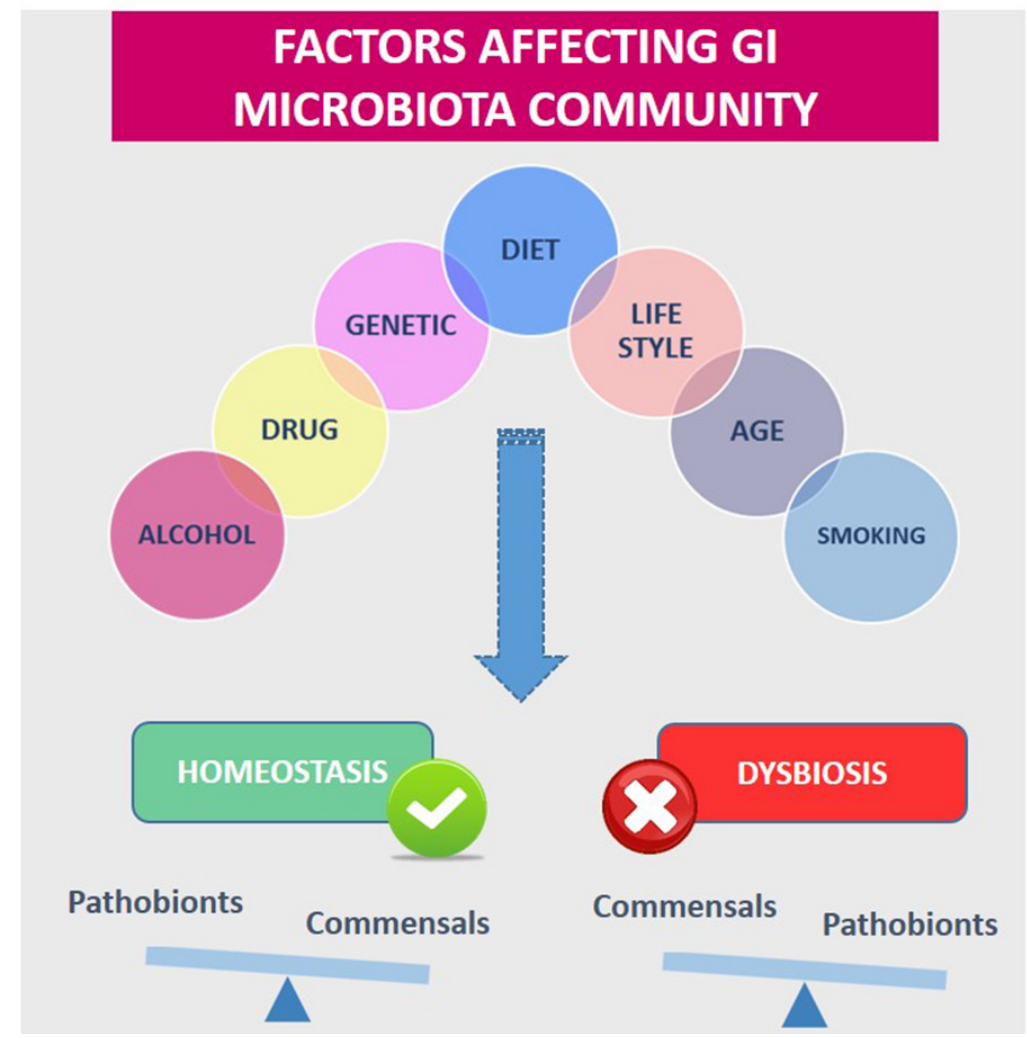

Figure 7: Diet and other environmental factors influence gastrointestinal Microbiota (GI) homeostasis or dysbiosis.

\section{GI MICROBIOTA FUNCTIONS}

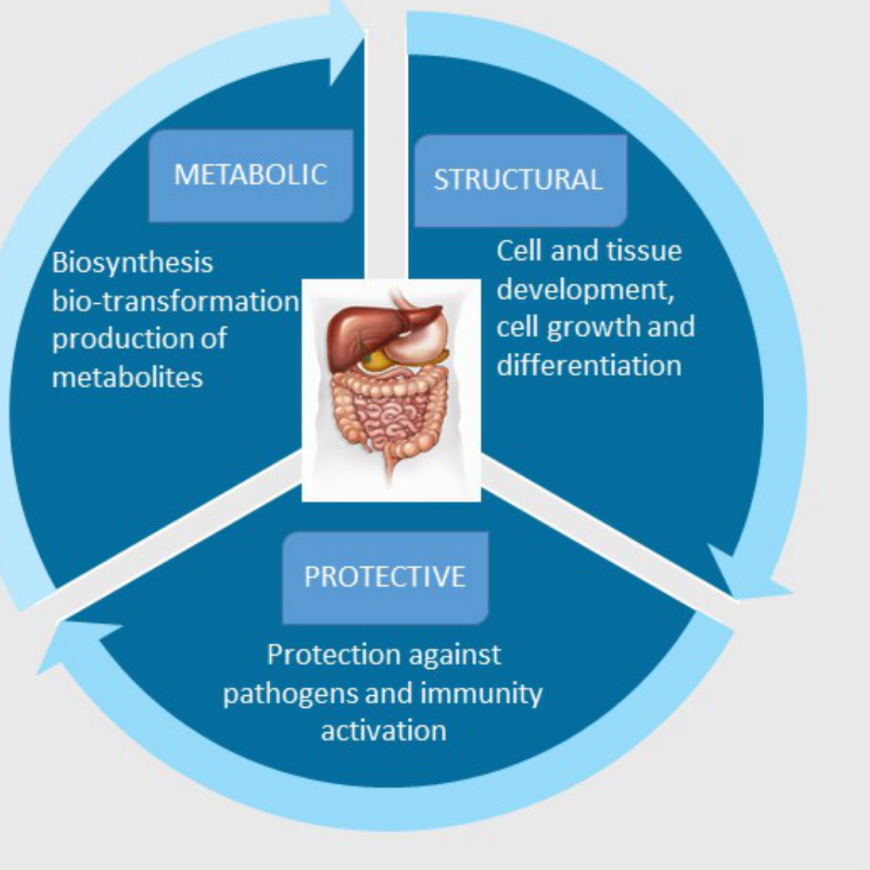

Figure 8: The gastrointestinal (GI) microbiota functions in maintenance of health, including protective, structural, and metabolic roles. 
hypercholesterolemia, and this ability might contribute to its beneficial effects [102]. Specifically, in an obese mice model, a water extract of G. lucidum mycelium was able to maintain the intestinal barrier integrity, reduce metabolic endotoxemia, and reverse high-fat diet-induced gut dysbiosis. These effects were correlated to decreases in both the Firmicutes-to-Bacteroidetes ratio and endotoxinbearing Proteobacteria levels. In addition, increases in Roseburia and Clostridium clusters XIVa and XVIII were also observed [103]. Similar data was reported by Meneses et al. [104], who demonstrated that G. lucidum extract modulated GI microbiota composition, with an increase of the Lactobacillus genus level in a model of mice fed with a high-cholesterol diet.

Further studies in humans are still needed to better define the mechanisms by which G. lucidum can enhance the GI microbiota health. Understanding the physiological mechanisms by which G. lucidum exert beneficial effects on GI microbiota would contribute to the success of future clinical trials aimed to investigate its potential for the treatment of GI dysbiosis-related diseases. The assessment of scientific evidence could allow the identification of specific nutraceutical interventions for health improvement by promoting intestinal homeostasis. Within this scenario, it could be interesting to investigate the nutraceutical effects of G. lucidum on GI microbiota composition and dynamics of $\mathrm{BC}$ patients.

\section{CONCLUSIONS}

Wild mushrooms have been widely used as human food for centuries and have been appreciated for their textures and flavors, as well as for suggested medicinal and tonic characteristics. However, the awareness of mushrooms as a healthy food and as an important source of biologically active substances with medicinal potentials has only recently emerged. Various activities of mushrooms have been studied, including antibacterial, antifungal, antioxidant, antiviral, antitumor, cytostatic, immunosuppressive, antiallergic, antiatherogenic, hypoglycemic, anti-inflammatory, and hepatoprotective activities [95, 105-107]. In this review, we collected evidence of 2 mushrooms (G. lucidum and G. frondosa) that have potential antitumor properties and, in particular, we focused on these benefits in BC.

It is estimated that half of the 5 million metric tons of mushrooms that are cultivated annually might contain functional or medicinal properties that may be used as a source of biologically and physiologically active substances [108]. Therefore, it is important to understand the isolation, structural characterization, and standardization of mushroom compounds with potential antitumor properties. Macrofungi and, in particular, the so-called medicinal mushrooms, may provide potent compounds with the potential to be used in the prevention and treatment of cancer. However, most of the research reviewed here is relatively recent and has been based on experiments with tumor cell lines or animal models. In fact, findings from many in vitro studies and animal models have allowed scientists to begin to clarify the molecular mechanisms involved in anticancer activities. Only a small amount of research has been performed at the level of clinical trials in patients. Therefore, despite the promising published data, more work needs to be completed to define the use of mushrooms, or their isolated compounds, in the prevention and treatment of cancer.

Most of the studies included in this review do not provide clear and unbiased evidence to support the upfront use of G. lucidum in the treatment of cancer patients. There is lack of evidence to support the use of G. lucidum in advanced cancer therapy to improve longterm survival. We do not recommend administration of G. lucidum preparations as a single treatment to patients with metastatic cancer. However, the results of this review suggest that a better response may be expected when a G. lucidum preparation is incorporated as an integrative to conventional $\mathrm{CT}$ and/or RT regimens. Therapeutic approaches that incorporate G. lucidum are 1.25 times more likely to yield better tumor response than those do not. Further, G. lucidum preparations can be administered in order to counter the immunosuppressive effects of CT and RT [9], especially in terms of T-lymphocyte depletion. Similar to other natural remedies, G. lucidum is welltolerated by cancer patients, which leads to better QoL and relatively improved Performance Status (Karnofsky) scores. No severe toxicity has been observed according to current evidence of the use of G. lucidum.

Still, current evidence does not support the routine use of G. lucidum in all cancer patients. The decision whether to use a G. lucidum preparation in an anticancer regimen should be made after careful consideration of the cost-benefit potentials and patients' preferences. Currently, the evidence for using G. lucidum for cancer is sparse and the methodological quality of the trials is poor. As a result, we have only been able to draw a few definite conclusions from the evidence. The lack of standardization in several aspects of the included trials, such as nonuniform preparation and administration of G. lucidum and failure to include key information in the published reports, decrease the reliability and validity of the original trials.

A phase I/II trial of a polysaccharide extract from G. frondosa in BC patients demonstrated its activity on some immunologic parameters in the peripheral blood, which has a stimulatory effect on some parameters and a suppressive effect on others. It is interesting to note that no side effects or apparent clinical changes were reported. The most prominent functional changes were increased production of IL-2, IL-10, TNF- $\alpha$, and IFN- $\gamma$ by subsets of $\mathrm{T}$ cells. The authors concluded that the clinical effects of $G$. frondosa in cancer prevention or treatment remain uncertain. 
In conclusion, most of the research reviewed here is relatively recent and has been based on tumor cell lines or animal models. To date, little work has been performed at the level of clinical trials in patients. Therefore, despite the promising published data, more work needs to be completed to clarify the use of mushrooms, or their isolated extracts, in the prevention and treatment of $\mathrm{BC}$.

\section{MATERIALS AND METHODS}

\section{Literature review}

Studies were identified by conducting searches of several electronic databases: the Cochrane Library, Pubmed, EMBASE, AMED, Scopus, the National Institutes of Health, and the National Center for Complementary and Alternative Medicine (nccam.nih. gov/clinicaltrials/alltrials.htm). Eligible studies were published from January 1971 to June 30, 2017.

\section{Study selection and data extraction}

The following search terms were used for the data search: mushroom, breast cancer, immunomodulatory, side effects, Microbiota, G. lucidum, and G. frondosa. Inclusion criteria also included publication in the English language and publication between 1971 and 2017.

Two researchers (RDF, VQ) reviewed the list of unique articles for studies that fit the inclusion criteria.

\section{ACKNOWLEDGMENTS}

The authors are grateful to Dr Alessandra Pino of the Department of Agri-Food and Environmental Systems Management, University of Catania, Italy for her support in the writing of portions of the manuscript, namely the microbiota paragraph.

This study was supported by the "Ricerca Corrente of the Italian Ministry of Health 2016, Line 4-Solid Tumors, Translational Research Improves Diagnosis \& Care."

We thank A.V.D Reform, Noceto, Parma (Italy) for supporting us with a scholarship. We thank experts from BioMed Proofreading ${ }^{\circledR} L L C$ for editing the English text.

The authors have declared that no competing interests exist.

\section{CONFLICTS OF INTEREST}

The authors declare no conflicts of interest.

\section{REFERENCES}

1. National Institutes of Health. National Center for Complementary and Integrative Health, Complementary, alternative, or integrative health: what's in a name? (homepage on Internet). March 2015. Online document at: https://nccih.nih.gov/health/integrative-health Accessed August 7, 2017.

2. Lim EJ, Vardy JL, Oh BS, Dhillon HM. A Scoping Review on Models of Integrative Medicine: What Is Known from the Existing Literature? J Altern Complement Med. 2017; 23:8-17. https://doi.org/10.1089/acm.2016.0263.

3. Berretta M, Della Pepa C, Tralongo P, Fulvi A, Martellotta F, Lleshi A, Nasti G, Fisichella R, Romano C, De Divitiis C, Taibi R, Fiorica F, Di Francia R, et al. Use of Complementary and Alternative Medicine (CAM) in cancer patients: an Italian multicenter survey. Oncotarget. 2017; 8:24401-14. https://doi.org/10.18632/oncotarget.14224.

4. National Institutes of Health. National Center for Complementary and Integrative Health. CAM use by race and ethnicity among adults-2007 [homepage on Internet]. December 2008. Online document at: https://nccih.nih.gov/ research/statistics/2007/camsurvey_fs 1.htm Accessed May 10, 2016.

5. Xue CC, Zhang AL, Lin V, Da Costa C, Story DF. Complementary and alternative medicine use in Australia: a national population-based survey. J Altern Complement Med. 2007; 13:643-50. https://doi.org/10.1089/ acm.2006.6355.

6. Steward BW, Kleihues P. World Health organization, World Cancer Report 2003. IARC Press. 2003.

7. Gaitanidis A, Alevizakos M, Taslikidis C, Tsaroucha A, Simopoulos C, Pitiakoudis M. Refusal of cancer-direct surgery by breast cancer patients: risk factors and survival outcomes. Clin Breast Cancer. 2017 Jul 18. https://doi. org/10.1016/j.clbc.2017.07.010. [Epub ahead of print]

8. Oncology Nursing Society (ONS). Chemotherapy and Biotherapy guidelines and recommendations for practice. Oncology Nursing Society. 2005.

9. Jin X, Ruiz Beguerie J, Sze DM, Chan GC. Ganoderma lucidum (Reishi mushroom) for cancer treatment. Cochrane Database Syst Rev. 2016; 4:CD007731.

10. Jiang J, Sliva D. Novel medicinal mushroom blend suppresses growth and invasiveness of human breast cancer cells. Int J Oncol. 2010; 37:1529-36.

11. Barbieri A, Quagliariello V, Del Vecchio V, Falco M, Luciano A, Amruthraj NJ, Nasti G, Ottaiano A, Berretta M, Iaffaioli RV, Arra C. Anticancer and Anti-Inflammatory Properties of Ganoderma lucidum Extract Effects on Melanoma and Triple-Negative Breast Cancer Treatment. Nutrients. 2017; 9:E210. https://doi.org/10.3390/ nu9030210.

12. Masuda Y, Nakayama Y, Tanaka A, Naito K, Konishi M. Antitumor activity of orally administered maitake $\alpha$-glucan by stimulating antitumor immune response in murine tumor. PLoS One. 2017; 12:e0173621. https://doi.org/10.1371/ journal.pone. 0173621 .

13. Alonso EN, Orozco M, Eloy Nieto A, Balogh GA. Genes related to suppression of malignant phenotype induced by 
Maitake D-Fraction in breast cancer cells. J Med Food. 2013; 16:602-17. https://doi.org/10.1089/jmf.2012.0222.

14. Meng X, Liang H, Luo L. Antitumor polysaccharides from mushrooms: a review on the structural characteristics, antitumor mechanisms and immunomodulating activities. Carbohydr Res. 2016; 424:30-41. https://doi.org/10.1016/j. carres.2016.02.008.

15. Cao Y, Wu SH, Dai YC. Species clarification of the prize medicinal Ganoderma mushroom "Lingzhi". Fungal Divers. 2012; 56:49-62. https://doi.org/10.1007/ s13225-012-0178-5.

16. Baby S, Johnson AJ, Govindan B. Secondary metabolites from Ganoderma. Phytochemistry. 2015; 114:66-101. https://doi.org/10.1016/j.phytochem.2015.03.010.

17. Hennicke F, Cheikh-Ali Z, Liebisch T, Maciá-Vicente JG, Bode HB, Piepenbring M. Distinguishing commercially grown Ganoderma lucidum from Ganoderma lingzhi from Europe and East Asia on the basis of morphology, molecular phylogeny, and triterpenic acid profiles. Phytochemistry. 2016; 127:29-37. https://doi.org/10.1016/j. phytochem.2016.03.012.

18. Saltarelli R, Ceccaroli P, Buffalini M, Vallorani L, Casadei L, Zambonelli A, Iotti M, Badalyan S, Stocchi V. Biochemical characterization and antioxidant and antiproliferative activities of different Ganoderma collections. J Mol Microbiol Biotechnol. 2015; 25:16-25. https://doi.org/10.1159/000369212.

19. Bernicchia A. Polyporaceae s.1. Edizioni Candusso. 2005. pp. 1-808.

20. Bhosle S, Ranadive K, Bapat G, Garad S, Deshpande G, Vaidya J. Taxonomy and Diversity of G. from the Western parts of Maharashtra. India: Mycosphere; 2010. pp. 249-62.

21. Ryvarden L, Melo I. Poroid fungi of Europe. Synopsis fungorum 31. 2014. pp. 1-455.

22. Ryvarden L. Studies in neotropical polypores 2: a preliminary key to neotropical species of $G$. with a laccate pileus. Mycologia. 2000; 92:180-91. https://doi. org/10.2307/3761462.

23. Deslandes Y, Marchessault RH, Sarko A. Packing Analysis of Carbohydrates and Polysaccharides Triple-Helical Structure of (1-]3)-Beta-D-Glucan. Macromolecules. 1980; 13:1466-71. https://doi.org/10.1021/ma60078a020.

24. Borchers AT, Stern JS, Hackman RM, Keen CL, Gershwin ME. Mushrooms, tumors, and immunity. Proc Soc Exp Biol Med. 1999; 221:281-93. https://doi. org/10.3181/00379727-221-44412.

25. Wu GS, Lu JJ, Guo JJ, Li YB, Tan W, Dang YY, Zhong ZF, Xu ZT, Chen XP, Wang YT. Ganoderic acid DM, a natural triterpenoid, induces DNA damage, G1 cell cycle arrest and apoptosis in human breast cancer cells. Fitoterapia. 2012; 83:408-14. https://doi.org/10.1016/j.fitote.2011.12.004.

26. Miyamoto I, Liu J, Shimizu K, Sato M, Kukita A, Kukita T, Kondo R. Regulation of osteoclastogenesis by ganoderic acid DM isolated from Ganoderma lucidum.
Eur J Pharmacol. 2009; 602:1-7. https://doi.org/10.1016/j. ejphar.2008.11.005.

27. Chen NH, Liu JW, Zhong JJ. Ganoderic acid T inhibits tumor invasion in vitro and in vivo through inhibition of MMP expression. Pharmacol Rep. 2010; 62:150-63. https:// doi.org/10.1016/S1734-1140(10)70252-8.

28. Schwartz B, Hadar Y. Possible mechanisms of action of mushroom-derived glucans on inflammatory bowel disease and associated cancer. Ann Transl Med. 2014; 2:19.

29. Rice PJ, Adams EL, Ozment-Skelton T, Gonzalez AJ, Goldman MP, Lockhart BE, Barker LA, Breuel KF, Deponti WK, Kalbfleisch JH, Ensley HE, Brown GD, Gordon S, Williams DL. Oral delivery and gastrointestinal absorption of soluble glucans stimulate increased resistance to infectious challenge. J Pharmacol Exp Ther. 2005; 314:1079-86. https://doi.org/10.1124/jpet.105.085415.

30. Sandvik A, Wang YY, Morton HC, Aasen AO, Wang JE, Johansen FE. Oral and systemic administration of betaglucan protects against lipopolysaccharide-induced shock and organ injury in rats. Clin Exp Immunol. 2007; 148:16877. https://doi.org/10.1111/j.1365-2249.2006.03320.x.

31. Masuda Y, Inoue H, Ohta H, Miyake A, Konishi M, Nanba $H$. Oral administration of soluble $\beta$-glucans extracted from Grifola frondosa induces systemic antitumor immune response and decreases immunosuppression in tumorbearing mice. Int J Cancer. 2013; 133:108-19. https://doi. org/10.1002/ijc.27999.

32. Kennedy AD, Willment JA, Dorward DW, Williams DL, Brown GD, DeLeo FR. Dectin-1 promotes fungicidal activity of human neutrophils. Eur J Immunol. 2007; 37:467-78. https://doi.org/10.1002/eji.200636653.

33. Taylor ME, Drickamer K. Paradigms for glycan-binding receptors in cell adhesion. Curr Opin Cell Biol. 2007; 19:572-77. https://doi.org/10.1016/j.ceb.2007.09.004.

34. Herre J, Willment JA, Gordon S, Brown GD. The role of Dectin-1 in antifungal immunity. Crit Rev Immunol. 2004; 24:193-203. https://doi.org/10.1615/CritRevImmunol.v24. i3.30.

35. Willment JA, Marshall AS, Reid DM, Williams DL, Wong SY, Gordon S, Brown GD. The human beta-glucan receptor is widely expressed and functionally equivalent to murine Dectin-1 on primary cells. Eur J Immunol. 2005; 35:153947. https://doi.org/10.1002/eji.200425725.

36. Herre J, Marshall AS, Caron E, Edwards AD, Williams DL, Schweighoffer E, Tybulewicz V, Reis e Sousa C, Gordon $\mathrm{S}$, Brown GD. Dectin-1 uses novel mechanisms for yeast phagocytosis in macrophages. Blood. 2004; 104:4038-45. https://doi.org/10.1182/blood-2004-03-1140.

37. Inoue A, Kodama N, Nanba H. Effect of maitake (Grifola frondosa) D-fraction on the control of the T lymph node Th-1/Th-2 proportion. Biol Pharm Bull. 2002; 25:536-40. https://doi.org/10.1248/bpb.25.536.

38. Masuda Y, Ito K, Konishi M, Nanba H. A polysaccharide extracted from Grifola frondosa enhances the anti-tumor 
activity of bone marrow-derived dendritic cell-based immunotherapy against murine colon cancer. Cancer Immunol Immunother. 2010; 59:1531-41. https://doi. org/10.1007/s00262-010-0880-7.

39. Zhang J, Tang Q, Zimmerman-Kordmann M, Reutter W, Fan H. Activation of B lymphocytes by GLIS, a bioactive proteoglycan from Ganoderma lucidum. Life Sci. 2002; 71:623-38. https://doi.org/10.1016/ S0024-3205(02)01690-9.

40. Kodama N, Komuta K, Nanba H. Can maitake MD-fraction aid cancer patients? Altern Med Rev. 2002; 7:236-39.

41. Liu J, Gunn L, Hansen R, Yan J. Combined yeast-derived beta-glucan with anti-tumor monoclonal antibody for cancer immunotherapy. Exp Mol Pathol. 2009; 86:208-14. https:// doi.org/10.1016/j.yexmp.2009.01.006.

42. Zaidman BZ, Yassin M, Mahajna J, Wasser SP. Medicinal mushroom modulators of molecular targets as cancer therapeutics. Appl Microbiol Biotechnol. 2005; 67:453-68. https://doi.org/10.1007/s00253-004-1787-z.

43. Liu C, Dunkin D, Lai J, Song Y, Ceballos C, Benkov K, Li XM. Anti-inflammatory Effects of Ganoderma lucidum Triterpenoid in Human Crohn's Disease Associated with Downregulation of NF- $\mathrm{B}$ Signaling. Inflamm Bowel Dis. 2015; 21:1918-25. https://doi.org/10.1097/ MIB.0000000000000439.

44. Ding H, Zhou M, Zhang RP, Xu SL. [Ganoderma lucidum extract protects dopaminergic neurons through inhibiting the production of inflammatory mediators by activated microglia]. Sheng Li Xue Bao. 2010; 62:547-54.

45. Preuss HG, Echard B, Bagchi D, Perricone NV. Maitake mushroom extracts ameliorate progressive hypertension and other chronic metabolic perturbations in aging female rats. Int J Med Sci. 2010; 7:169-80. https://doi.org/10.7150/ ijms.7.169.

46. Rajamahanty S, Louie B, O’Neill C, Choudhury M, Konno $\mathrm{S}$. Possible disease remission in patient with invasive bladder cancer with D-fraction regimen. Int J Gen Med. 2009; 2:15-17.

47. Lee JS, Park SY, Thapa D, Choi MK, Chung IM, Park YJ, Yong CS, Choi HG, Kim JA. Grifola frondosa water extract alleviates intestinal inflammation by suppressing TNFalpha production and its signaling. Exp Mol Med. 2010; 42:143-54. https://doi.org/10.3858/emm.2010.42.2.016.

48. Frenkel M, Abrams DI, Ladas EJ, Deng G, Hardy M, Capodice JL, Winegardner MF, Gubili JK, Yeung KS, Kussmann H, Block KI. Integrating dietary supplements into cancer care. Integr Cancer Ther. 2013; 12:369-84. https://doi.org/10.1177/1534735412473642.

49. Gill BS, Navgeet, Kumar S. Ganoderic acid targeting multiple receptors in cancer: in silico and in vitro study. Tumour Biol. 2016; 37:14271-90. https://doi.org/10.1007/ s13277-016-5291-8.

50. Hsu SC, Ou CC, Chuang TC, Li JW, Lee YJ, Wang V, Liu JY, Chen CS, Lin SC, Kao MC. Ganoderma tsugae extract inhibits expression of epidermal growth factor receptor and angiogenesis in human epidermoid carcinoma cells: in vitro and in vivo. Cancer Lett. 2009; 281:108-16. https://doi. org/10.1016/j.canlet.2009.02.032.

51. $\mathrm{Na} \mathrm{K}$, Li $\mathrm{K}$, Sang $\mathrm{T}$, Wu $\mathrm{K}$, Wang $\mathrm{Y}$, Wang $\mathrm{X}$. Anticarcinogenic effects of water extract of sporodermbroken spores of Ganoderma lucidum on colorectal cancer in vitro and in vivo. Int J Oncol. 2017; 50:1541-54. https:// doi.org/10.3892/ijo.2017.3939.

52. Chen Y, Lv J, Li K, Xu J, Li M, Zhang W, Pang X. Sporoderm-Broken Spores of Ganoderma lucidum Inhibit the Growth of Lung Cancer: Involvement of the Akt/mTOR Signaling Pathway. Nutr Cancer. 2016; 68:1151-60. https:// doi.org/10.1080/01635581.2016.1208832.

53. Pyo P, Louie B, Rajamahanty S, Choudhury M, Konno S. Possible immunotherapeutic potentiation with D-fraction in prostate cancer cells. J Hematol Oncol. 2008; 1:25. https:// doi.org/10.1186/1756-8722-1-25.

54. Soares R, Meireles M, Rocha A, Pirraco A, Obiol D, Alonso E, Joos G, Balogh G. Maitake (D fraction) mushroom extract induces apoptosis in breast cancer cells by BAK-1 gene activation. J Med Food. 2011; 14:563-72. https://doi. org/10.1089/jmf.2010.0095.

55. Kodama N, Komuta K, Nanba H. Effect of Maitake (Grifola frondosa) D-Fraction on the activation of NK cells in cancer patients. J Med Food. 2003; 6:371-77. https://doi. org/10.1089/109662003772519949.

56. Deng G, Lin H, Seidman A, Fornier M, D'Andrea G, Wesa K, Yeung S. Cunningham-Rundles, Vickers AJ, Cassileth B. A phase I/II trial of a polysaccharide extract from $\mathrm{G}$. frondosa (Maitake mushroom) in breast cancer patients: immunological effects. J Cancer Res Clin Oncol. 2009; 135:1215-21. https://doi.org/10.1007/s00432-009-0562-z.

57. Said TK, Moraes RC, Singh U, Kittrell FS, Medina D. Cyclin-dependent kinase (cdk) inhibitors/cdk4/cdk2 complexes in early stages of mouse mammary preneoplasia. Cell Growth Differ. 2001; 12:285-95.

58. Amemiya Y, Yang W, Benatar T, Nofech-Mozes S, Yee A, Kahn H, Holloway C, Seth A. Insulin like growth factor binding protein-7 reduces growth of human breast cancer cells and xenografted tumors. Breast Cancer Res Treat. 2011; 126:373-84. https://doi.org/10.1007/ s10549-010-0921-0.

59. Georgescu MM. PTEN tumor suppressor network in PI3KAkt pathway control. Genes Cancer. 2010; 1:1170-77. https://doi.org/10.1177/1947601911407325.

60. Richardson AL, Wang ZC, De Nicolo A, Lu X, Brown M, Miron A, Liao X, Iglehart JD, Livingston DM, Ganesan S. X chromosomal abnormalities in basal-like human breast cancer. Cancer Cell. 2006; 9:121-32. https://doi. org/10.1016/j.ccr.2006.01.013.

61. van 't Veer LJ, Dai H, van de Vijver MJ, He YD, Hart AA, Mao M, Peterse HL, van der Kooy K, Marton MJ, Witteveen AT, Schreiber GJ, Kerkhoven RM, Roberts C, et al. Gene expression profiling predicts clinical outcome 
of breast cancer. Nature. 2002; 415:530-36. https://doi. org/10.1038/415530a.

62. Doughtery ER, Jianping H, Bittner ML. Validation of computational methods in genomics. Curr Genomics. 2007; 8:1-19. https://doi.org/10.2174/138920207780076956.

63. Rahman M, Chan AP, Tang M, Tai IT. A peptide of SPARC interferes with the interaction between caspase 8 and $\mathrm{Bcl} 2$ to resensitize chemoresistant tumors and enhance their regression in vivo. PLoS One. 2011; 6:e26390. https://doi. org/10.1371/journal.pone.0026390.

64. Li C, Zhou HM. The role of manganese superoxide dismutase in inflammation defense. Enzyme Res. 2011; 2011:387176. https://doi.org/10.4061/2011/387176.

65. Sotgia F, Martinez-Outschoorn UE, Lisanti MP. Mitochondrial oxidative stress drives tumor progression and metastasis: should we use antioxidants as a key component of cancer treatment and prevention? BMC Med. 2011; 9:62-66. https://doi.org/10.1186/1741-7015-9-62.

66. Arrieta MC, Stiemsma LT, Amenyogbe N, Brown EM, Finlay B. The intestinal microbiome in early life: health and disease. Front Immunol. 2014; 5:427. https://doi. org/10.3389/fimmu.2014.00427.

67. Saavedra JM, Dattilo AM. Early development of intestinal microbiota: implications for future health. Gastroenterol Clin North Am. 2012; 41:717-31. https://doi.org/10.1016/j. gtc.2012.08.001.

68. Goulet O. Potential role of the intestinal microbiota in programming health and disease. Nutr Rev. 2015 (Suppl 1); 73:32-40. https://doi.org/10.1093/nutrit/nuv039.

69. Chevalier C, Stojanović O, Colin DJ, Suarez-Zamorano N, Tarallo V, Veyrat-Durebex C, Rigo D, Fabbiano S, Stevanović A, Hagemann S, Montet X, Seimbille Y, Zamboni N, et al. Gut microbiota orchestrates energy homeostasis during cold. Cell. 2015; 163:1360-74. https:// doi.org/10.1016/j.cell.2015.11.004.

70. McKenney PT, Pamer EG. From hype to hope: the gut microbiota in enteric infectious disease. Cell. 2015; 163:1326-32. https://doi.org/10.1016/j.cell.2015.11.032.

71. Kamdar K, Khakpour S, Chen J, Leone V, Brulc J, Mangatu T, Antonopoulos DA, Chang EB, Kahn SA, Kirschner BS, Young G, DePaolo RW. Genetic and metabolic signals during acute enteric bacterial infection alter the microbiota and drive progression to chronic inflammatory disease. Cell Host Microbe. 2016; 19:21-31. https://doi.org/10.1016/j. chom.2015.12.006.

72. Akira S, Uematsu S, Takeuchi O. Pathogen recognition and innate immunity. Cell. 2006; 124:783-801. https://doi. org/10.1016/j.cell.2006.02.015.

73. de Martel C, Ferlay J, Franceschi S, Vignat J, Bray F, Forman D, Plummer M. Global burden of cancers attributable to infections in 2008: a review and synthetic analysis. Lancet Oncol. 2012; 13:607-15. https://doi. org/10.1016/S1470-2045(12)70137-7.
74. Carbonero F, Benefiel AC, Alizadeh-Ghamsari AH, Gaskins HR. Microbial pathways in colonic sulfur metabolism and links with health and disease. Front Physiol. 2012; 3:448. https://doi.org/10.3389/fphys.2012.00448.

75. Hawksworth GM, Hill MJ. Bacteria and the N-nitrosation of secondary amines. Br J Cancer. 1971; 25:520-26. https:// doi.org/10.1038/bjc.1971.66.

76. Schwabe RF, Jobin C. The microbiome and cancer. Nat Rev Cancer. 2013; 13:800-12. https://doi.org/10.1038/nrc3610.

77. Hajishengallis G, Darveau RP, Curtis MA. The keystonepathogen hypothesis. Nat Rev Microbiol. 2012; 10:717-25. https://doi.org/10.1038/nrmicro2873.

78. Yu G, Gail MH, Consonni D, Carugno M, Humphrys M, Pesatori AC, Caporaso NE, Goedert JJ, Ravel J, Landi MT. Characterizing human lung tissue microbiota and its relationship to epidemiological and clinical features. Genome Biol. 2016; 17:163. https://doi.org/10.1186/ s13059-016-1021-1.

79. Zitvogel L, Ayyoub M, Routy B, Kroemer G. Microbiome and anticancer immunosurveillance. Cell. 2016; 165:27687. https://doi.org/10.1016/j.cell.2016.03.001.

80. Jaworski DM, Namboodiri AM, Moffett JR. Acetate as metabolic and epigenetic modifier of cancer therapy. J Cell Biochem. 2016; 117:574-88. https://doi.org/10.1002/ jcb.25305.

81. Schug ZT, Vande Voorde J, Gottlieb E. The metabolic fate of acetate in cancer. Nat Rev Cancer. 2016; 16:708-17. https://doi.org/10.1038/nrc.2016.87.

82. Kilkkinen A, Rissanen H, Klaukka T, Pukkala E, Heliövaara M, Huovinen P, Männistö S, Aromaa A, Knekt P. Antibiotic use predicts an increased risk of cancer. Int J Cancer. 2008; 123:2152-55. https://doi.org/10.1002/ijc.23622.

83. Plottel CS, Blaser MJ. Microbiome and malignancy. Cell Host Microbe. 2011; 10:324-35. https://doi.org/10.1016/j. chom.2011.10.003.

84. Roberts MS, Magnusson BM, Burczynski FJ, Weiss M. Enterohepatic circulation: physiological, pharmacokinetic and clinical implications. Clin Pharmacokinet. 2002; 41:751-90. https://doi. org/10.2165/00003088-200241100-00005.

85. Woolcott CG, Shvetsov YB, Stanczyk FZ, Wilkens LR, White KK, Caberto C, Henderson BE, Le Marchand L, Kolonel LN, Goodman MT. Plasma sex hormone concentrations and breast cancer risk in an ethnically diverse population of postmenopausal women: the Multiethnic Cohort Study. Endocr Relat Cancer. 2010; 17:125-34. https://doi.org/10.1677/ERC-09-0211.

86. Flores R, Shi J, Fuhrman B, Xu X, Veenstra TD, Gail MH, Gajer P, Ravel J, Goedert JJ. Fecal microbial determinants of fecal and systemic estrogens and estrogen metabolites: a cross-sectional study. J Transl Med. 2012; 10:253. https:// doi.org/10.1186/1479-5876-10-253.

87. Goldin BR, Adlercreutz H, Gorbach SL, Warram JH, Dwyer JT, Swenson L, Woods MN. Estrogen excretion patterns 
and plasma levels in vegetarian and omnivorous women. N Engl J Med. 1982; 307:1542-47. https://doi.org/10.1056/ NEJM198212163072502.

88. Adlercreutz $\mathrm{H}$, Pulkkinen $\mathrm{MO}$, Hämäläinen $\mathrm{EK}$, Korpela JT. Studies on the role of intestinal bacteria in metabolism of synthetic and natural steroid hormones. J Steroid Biochem. 1984; 20:217-29. https://doi. org/10.1016/0022-4731(84)90208-5.

89. Heimer GM, Englund DE. Enterohepatic recirculation of oestriol studied in cholecystectomized and non-cholecystectomized menopausal women. Ups J Med Sci. 1984; 89:107-15. https://doi. org/10.3109/03009738409178470.

90. Kwa M, Plottel CS, Blaser MJ, Adams S. The Intestinal Microbiome and Estrogen Receptor-Positive Female Breast Cancer. JNCI J Natl Cancer Inst. 2016; 108.

91. Beaud D, Tailliez P, Anba-Mondoloni J. Genetic characterization of the beta-glucuronidase enzyme from a human intestinal bacterium, Ruminococcus gnavus. Microbiology. 2005; 151:2323-30. https://doi.org/10.1099/ mic.0.27712-0.

92. Dabek M, McCrae SI, Stevens VJ, Duncan SH, Louis P. Distribution of beta-glucosidase and beta-glucuronidase activity and of beta-glucuronidase gene gus in human colonic bacteria. FEMS Microbiol Ecol. 2008; 66:487-95. https://doi.org/10.1111/j.1574-6941.2008.00520.x.

93. Gloux K, Berteau O, El Oumami H, Béguet F, Leclerc M, Doré J. A metagenomic $\beta$-glucuronidase uncovers a core adaptive function of the human intestinal microbiome. Proc Natl Acad Sci USA. 2011 (Suppl 1); 108:4539-46. https:// doi.org/10.1073/pnas.1000066107.

94. Goedert JJ, Jones G, Hua X, Xu X, Yu G, Flores R, Falk RT, Gail MH, Shi J, Ravel J, Feigelson HS. Investigation of the Association Between the Fecal Microbiota and Breast Cancer in Postmenopausal Women: a Population-Based Case-Control Pilot Study. JNCI J Natl Cancer Inst. 2015; 107: djv147. https://doi.org/10.1093/jnci/djv147.

95. Wasser SP. Medicinal mushroom science: current perspectives, advances, evidences, and challenges. Biomed J. 2014; 37:345-56. https://doi. org/10.4103/2319-4170.138318.

96. De Silva D, Rapior S, Fons F, Bahkali A, Hyde K. Medicinal mushrooms in supportive cancer therapies: an approach to anti-cancer effects and putative mechanisms of action. Fungal Divers. 2012; 55:1-35. https://doi.org/10.1007/ s13225-012-0151-3.

97. Sanodiya BS, Thakur GS, Baghel RK, Prasad GB, Bisen PS. Ganoderma lucidum: a potent pharmacological macrofungus. Curr Pharm Biotechnol. 2009; 10:717-42. https://doi.org/10.2174/138920109789978757.

98. Lam KL, Cheung PC. Non-digestible long chain betaglucans as novel prebiotics. Bioactive Carbohydrates and
Dietary Fibre. 2013; 2:45-64. https://doi.org/10.1016/j. bcdf.2013.09.001.

99. Ren Z, Guo Z, Meydani SN, Wu D. White button mushroom enhances maturation of bone marrow-derived dendritic cells and their antigen presenting function in mice. J Nutr. 2008; 138:544-50. https://doi.org/10.1093/jn/138.3.544.

100. Wu D, Pae M, Ren Z, Guo Z, Smith D, Meydani SN. Dietary supplementation with white button mushroom enhances natural killer cell activity in C57BL/6 mice. J Nutr. 2007; 137:1472-77. https://doi.org/10.1093/ jn/137.6.1472.

101. Feeney MJ, Dwyer J, Hasler-Lewis CM, Milner JA, Noakes M, Rowe S, Wach M, Beelman RB, Caldwell J, Cantorna MT, Castlebury LA, Chang ST, Cheskin LJ, et al. Mushrooms and Health Summit proceedings. J Nutr. 2014; 144:1128S-36S. https://doi.org/10.3945/jn.114.190728.

102. Ferrão J, Bell V, Calabrese V, Pimentel L, Pintado M, Fernandes TH. Impact of Mushroom Nutrition on Microbiota and Potential for Preventative Health. Journal of Food and Nutrition Research. 2017; 5:226-33.

103. Chang CJ, Lin CS, Lu CC, Martel J, Ko YF, Ojcius DM, Tseng SF, Wu TR, Chen YY, Young JD, Lai HC. Ganoderma lucidum reduces obesity in mice by modulating the composition of the gut microbiota. Nat Commun. 2015; 6:7489. https://doi.org/10.1038/ncomms8489.

104. Meneses ME, Martínez-Carrera D, Torres N, SánchezTapia M, Aguilar-López M, Morales P, Sobal M, Bernabé T, Escudero H, Granados-Portillo O, Tovar AR. Hypocholesterolemic Properties and Prebiotic Effects of Mexican Ganoderma lucidum in C57BL/6 Mice. PLoS One. 2016; 11:e0159631. https://doi.org/10.1371/journal. pone. 0159631 .

105. Lindequist $U$, Niedermeyer TH, Jülich WD. The pharmacological potential of mushrooms. Evid Based Complement Alternat Med. 2005; 2:285-99. https://doi. org/10.1093/ecam/neh107.

106. Brandalise F, Cesaroni V, Gregori A, Repetti M, Romano C, Orrù G, Botta L, Girometta C, Guglielminetti ML, Savino E, Rossi P. Dietary Supplementation of Hericium erinaceus Increases Mossy Fiber-CA3 Hippocampal Neurotransmission and Recognition Memory in WildType Mice. Evid Based Complement Alternat Med. 2017; 2017:3864340. https://doi.org/10.1155/2017/3864340.

107. Rossi P, Buonocore D, Altobelli E, Brandalise F, Cesaroni V, Iozzi D, Savino E, Marzatico F. Improving training condition assessment in endurance cyclists: effects of Ganoderma lucidum and Ophiocordyceps sinensis dietary supplementation. Evid Based Complement Alternat Med. 2014; 2014:979613. https://doi.org/10.1155/2014/979613.

108. Cheung LM, Cheung PC, Ooi VE. Antioxidant activity and total phenolics od edible mushroom extracts. Food Chem. 2003; 81:249-55. https://doi.org/10.1016/ S0308-8146(02)00419-3. 